\title{
Üniversite Öğrencilerinin Okuma Alışkanlığı: Ankara Üniversitesi Örneği
}

\author{
Reading Habit of University Students: The Model of \\ Ankara University
}

\author{
Hüseyin ODABAŞ ${ }^{*}$ \\ Z. Yonca ODABAŞ ${ }^{* *}$ \\ Coşkun POLAT $^{* * *}$
}

\section{Öz}

Okuma alışkanlığı, okuma eyleminin sürekli, düzenli ve eleştirel olarak sürdürülmesidir. Okuma alışkanlığının özünde sürdürülebilirlik yaklaşımı bulunmaktadır. Sürdürülebilir okuma alışkanlığı, bireyin yaşamının her döneminde okuma eylemini kalıcı ve düzenli olarak devam ettirmesini ifade eder. Türkiye'de okuma kültürünün gelişmiş ülke ortalamalarının oldukça altında olduğu bilinmektedir. Bu bakımdan çalışmanın temel amacı Türkiye'nin genel yapısında gözlemlenen bu olumsuz tablonun üniversite öğrencileri üzerine ne düzeyde yansıdığına ilişkin durum saptamasıdır. Çalışmada ilk olarak okuma alışkanlığı kavramsal olarak irdelenmekte, daha sonra Türkiye'de okuma alışkanlığının durumu ortaya konmakta ve son olarak da Ankara Üniversitesi lisans öğrencileri üzerinde yapılan anket uygulamasının sonuçları değerlendirilmektedir. Çıkan sonuçlar yüksek öğrenim boyunca öğrencilerin okuma becerisinde gelişme olduğunu, buna karşın yeterli okuma alışkanlığına sahip olmadıklarını göstermektedir.

\footnotetext{
*Yrd. Doç. Dr.; Atatürk Üniversitesi Bilgi ve Belge Yönetimi Bölümü, (odabashuseyin@gmail.com).

A*ş. Gör.; Ankara Üniversitesi Sosyoloji Bölümü, (yoncaodabas@gmail.com).

Yrd. Doç.; Dr. Atatürk Üniversitesi Bilgi ve Belge Yönetimi Bölümü, (polatcoskun@gmail.com).
} 
Anahtar sözcükler: Okuma alışkanlığı, Okuma, Kültür, Türkiye

\section{Abstract}

Reading habit is the realization of reading activity in a continuous, systematic and critical way. In the essence of this habit, the marking approach is sustainability. Sustainable reading habit is that an individual continues with his/her reading activity at every of his/her life's phases, and in a permanent and proper form. It is known that, reading habit as a cultural attitude in Turkey is on the average lower than those being exercised in developed countries. This study aims at examining effects of this negative situation on university students. In the first part of the paper, conceptual analysis of reading habit is made and then, the intensity of the reading habit in Turkey is examined. Finally, the results of survey study conducted among Ankara University students are evaluated. Results reveal that although there seems to exist a relative developedness in reading habits of the sample, inadequacies are discernible.

Keywords: Reading habits, Reading, Culture, Turkey

\section{Giriş}

Hızla gelişen bilgi ve iletişim teknolojileri, içinde bulunduğumuz çağın bilgi çağı olarak adlandırılmasına, bireysel ve toplumsal hayatın özünde önemli değişikliklerin yaşanmasına neden olmuştur. Bu çağda üretilen bilgiler kısa bir süre sonra geçerliliğini ve güncelliğini yitirmektedir. Bu nedenle eğitim kurumları tarafından verilen eğitim, kısa bir süre sonra bireysel yaşamın gereksinimlerini karşılamada yetersiz kalmaktadır. Dolayısıyla çağın gereksinimlerini karşılama konusunda yaşam boyu öğrenme becerisi, geçmişten olduğundan daha önemli bir eğitim-öğretim aracı olmuştur.

$\mathrm{Bu}$ dönemde bireysel ve toplumsal gereksinimleri karşılamak için yaşam boyu öğrenme ne kadar önemli ise, bireyin yaşam boyu öğrenebilme becerisi kazanabilmesi için okuma alışkanlığına sahip olması da o kadar önemlidir. Diğer bir ifade ile okuma alışkanlığı yaşam boyu öğrenmenin temelidir. Bireyin yaşam boyu öğrenen bir kişi olabilmesi için okuma eylemini kendinde ömür boyu düzenli olarak yaşatması gerekmektedir. 


\section{Okuma Alışkanlığı}

Okuma, dil kurallarına uyularak oluşturulmuş yazılı iletileri duyu organları yoluyla algılayıp kavrama, anlamlandırma, yorumlama, düşünce yürütme ve yargıya varma evrelerinden oluşan bütün bir süreçtir. Bu bakımdan okuma duyu organlarının ortaklaşa yaptığı bir etkinliktir.

Kuşkusuz bilgi sahibi olmanın gezme, eğitim programlarına katılma ve televizyon izleme gibi çok çeşitli yolları vardır. Ancak bilgi sağlamanın dışında farklı birtakım kazanımlara da yol açması nedeniyle okuma bu yöntemlerin en etkili ve verimli olanıdır. Okuma bireyin bilgi edinebilmesi ve öğrenmesi sağlar. Bunun yanında okuma bireyin; (Koç ve Müftüoğlu, 2008, s. 62)

- davranış ve başkalarıyla ilişkilerini yönlendirir;

- $\quad$ iç dünyasını zenginleştirir;

- bakış açısını genişletir;

- çevresine önyargısız, yansız ve hoşgörülü bakmasını sağlar;

- $\quad$ beğeni düzeyini artııı;

- düşünme ve yaratma özgürlüğü ile değerlendirme alışkanlığı kazanmasını sağlar.

Okuma, bireyin dil kullanım becerisini artıran, daha derin düşünmesi ve dolayısıyla daha doğru kararlar alabilmesi için gereksinim duyulan önemli bir araçtır. Okuma, bireysel bir faaliyettir. Ancak okumanın, toplumun olayları daha rasyonel biçimde yönetebilmesini sağlamak gibi toplumsal bir işlevi de vardır. Okuma, sürekli öğrenme ve dolayısıyla zaman içinde doğan gereksinimleri karşılama yöntemlerinin önemlileri arasında yer alır. Bu bakımdan okuma eylemi, yalnızca zaman içinde doğan bilgi gereksinimini karşılamak için yapılan 'süreksiz okuma' ve temel bir yaşamsal gereksinim bağlamında yapılan 'sürekli okuma' şeklinde iki tür altında sınıflandırılabilir. Örneğin her gün belli bir sürede yapılan okuma sürekli okuma türünü ifade ederken, çevreden alınan bir uyarı sonucunda yapılan ve periyodik olmayan okuma ise süreksiz okuma türü içinde yer almaktadır. Aynı zamanda okuma, okunan 
materyalin türüne göre de farklılıklar gösterebilmektedir. Her birey kendi eğilimine göre basılı ya da elektronik kaynaklar, kitap ya da süreli yayınlar gibi yayın türlerinden bilimsel ya da popüler konulara kadar çok çeşitli yayın ve konu türünü tercih edebilmektedir. Bu nedenle okunan yayının türü ve konusu, okuma eyleminin gelişmesinde rolü olan ve bu olgunun değerlendirilmesinde göz önünde bulundurulması gereken etkenlerden biridir.

Herhangi bir konu hakkında ortaya konan her farklı görüşün eşit oranda alınması ve doğru karara bu görüşlerin sentezlenerek varılması, karar alma yönteminin özünü oluşturur. Karar alma sürecinde olduğu gibi okuma eyleminin niteliği de yararlanılan yayın türüne ve alınan görüşlerin farklılığına bağlı olarak farklılaşır. Örneğin benzer kaynak ve benzer görüşlerden yararlanılarak sürdürülen okuma, bireyin her alanda tek yönlü hareket etmesine neden olur. Bu nedenle doğru okuma alışkanlığına, farklı yayın türlerinden ve farklı görüşlerden beslenilerek sahip olunmalıdır.

Okuma eylemi ile varılması gereken amaçlardan biri ve aynı zamanda söz konusu eylemin sürekli ve düzenli olarak sürdürülmesinin sonucu olarak ortaya çıkan bir başka beceri ise 'eleştirel okuma'dır. Eleştirel okuma bireyin sahip olduğu bilgi birikimi ile okuduğu konuyu sınama ve değerlendirmesidir. Eleştirel okuma, herhangi bir güncel olayı yüzeysel olarak okumaktan çok farklı bir eylemdir. Eleştirel okuma, okuma işlevinin büyük bir istek ve ilgi ile sürdürülmesini, tam olarak anlayabilmek için gerektiğinde yeniden okunmasını ve yazıda geçen olgu ve düşüncelerin dikkatle izlenmesini gerektirir.

Eleştirel okuma davranışı bireyin hangi kelime ve cümlelerin ne anlama geldiğini özenle takip ederek daha dikkatli düşünmesine yol açmakta ve bu durum, okuduğu konuyu daha geniş bir bakış açısıyla ele almasını sağlamaktadır. Dolayısıyla okuduğu metni eleştirel bir gözle okuyan birey, zihnini sürekli olarak yoklama ve canlı tutma becerisine de sahip olur.

Bireyin eleştirel okuma yetisine sahip olabilmesi için öncelikle etkin okuma becerisine sahip olması zorunludur. Etkin okuma, okuma eylemi sırasında bireyin fiziksel ve ruhsal olarak okuma atmosferini etkin bir şekilde yaşamasını ifade etmektedir. Etkin 
okuma, bireyin okuma sürecini sürekli olarak belli bir bilinç ve algı düzeyi üzerinde tutarak sürdürmesini ifade eder. Bireyin eleştirel bir yaklaşımla okuma yapabilmesi için, fiziksel ve ruhsal olarak okuma eylemine uygun şartlar içinde bulunması gerekmektedir. Okurken, anlamayı, düşünmeyi ve yorumlamayı engelleyen dış etkenlerden uzak durulması etkin okumanın gereklerinden biridir. Örneğin okuma eylemi sırasında müzik dinlemek ya da televizyon programına göz atmak bu engellerdendir. Benzer şekilde etkin okumayı engelleyen en yaygın sorunlardan biri de okuma sırasında başka düşüncelere dalarak okunan konunun özünden uzaklaşmaktır. Bu sorunları ortadan kaldırmanın yolu okuma eyleminin sessiz bir yerde ve uygun ergonomik koşullar içinde sürdürülmesini sağlamaktır.

Okuma konusunda yapılan bu değerlendirmelerde okuma eyleminin bir alışkanlık olarak nitelendirilebilmesi için bu eylemin belli bir sürekliliğe sahip olmasına, farklı görüşler ve kaynaklara bağlı olarak sürdürülmesine, etkin bir okuma sürecine bağlı olmasına ve aynı zamanda okunanların eleştirel bir bakış açısı ile değerlendirilmesine vurgu yapılmaktadır. O halde okuma alışkanlığı, insanların okuma eylemini bireysel gereksinimlerin bir gereği olarak sürekli, düzenli ve eleştirel bir biçimde sürdürmesidir (Yılmaz, 2004, s. 116; Yılmaz, 1993, s. 30). Okuma alışkanlığı, bireylerin yaşamları boyunca elde ettikleri bilgileri, becerileri, anlayışları güçlendirip artıran ve aynı zamanda bu değerlerin bireysel ve toplumsal yaşama uyarlanmasına olanak sağlayan beceridir.

Güçlü bir okuma alışkanlığının bir topluma kazandıracağı katkıları Phillip (2005), iki sınıf altında gruplandırmaktadır. Illki okumanın bireylere kazandıracağı mantıksal gelişim, ikincisi ise okuyan bireyin içinde bulunduğu sisteme katkı sağlayacağı ekonomik büyümedir. Okuma alışkanlığının bireyin bilgi okuryazarı olmasına katı sağlayıp sağlamadığı konusunda araştırmacılar arasında görüş ayrılıkları bulunsa da büyük bir kesimi olumlu yönde katkı sağladığını bildirmektedirler. Bunun yanı sıra okumanın bireyin zihinsel gelişimine önemli katıklar sağladığı konusunda görüş birliği vardır. Okuma eylemi, bireyin okunan olayları düşünerek, metinde geçen kişi ve yerleri zihinlerine kaydederek ve olaylar arasında bağ kurarak zihnini sürekli olarak canlı tutmasına katkı sağlamaktadır (Bamberger, 1990, s. 2). 
Diğer bir ifade ile okuma bireyin düşünmesini ve zihin egzersizi yapmasını sağlayan bir araçıı (Reading, 1997).

Belli bir zaman diliminde okuma eylemine ayrılan süreye ya da okunan yayın sayısına göre okur tiplerini belirlemeye yönelik bir takım standartlar bulunmaktadır. Örneğin American Library Association (ALA)'dan aktarımla Yılmaz (2004, s. 116) okuma alışkanlığı düzeylerini bireylerin bir yıl içinde okudukları kitap sayısına göre üç tür altında sınıflandırılmaktadır. Buna göre,

- $\quad$ yılda okuduğu kitap sayısı 5’i geçmeyen az okuyan okur tipi,

- $\quad$ yılda okuduğu toplam kitap sayısı 6 ile 11 arasında olanlar orta düzeyde okuyan okur tipi ve

- $\quad$ yılda okuduğu toplam kitap sayısı 12'yi aşan kişiler ise çok okuyan okur tipi olarak nitelendirilmektedir (ALA, 1978, s. 3).

Okuma alışkanlığı okuma eylemine olan eğilimin yansımasıdır ve her eğilimin derinliği söz konusu eğilime ne kadar erken çağlarda başlandığına bağlı olarak farklııklar gösterir. Bireysel alışkanlıkların güçlü olmasını sağlayan en önemli etken alışkanlığa yapılan eğilimin erken yaşlarda başlamasıdır. Okuma alışkanlığının da ilerleyen yaşlarda kalıcı olabilmesi için erken yaşlarda kazanılması önemlidir. Bu nedenle bireyin okuma alışkanı olmasında iki kurumun önemli görevleri vardır. Bunlardan ilki aile, ikincisi ise kütüphanelerin de içinde bulunduğu eğitim kurumlarıdır. Küçük yaşlardaki çocuklar öncelikle ebeveyn ve öğretmen, daha genel olarak aile büyükleri, yakınları ve kütüphaneciler gibi yaşam alanlarının içinde olan kişileri kendilerine örnek alırlar. Bu nedenle okuyan ve okumaya teşvik eden ebeveynin, öğretmenlerin, kütüphanecilerin ve çocuğun çevresinde bulunan diğer kişilerin, okuma alışkanlığı yüksek bir toplum yaratmada önemli rolleri bulunmaktadır. Dolayısıyla okumayan bir ailenin ya da öğretmenin çocuklara okumaları konusunda telkinde bulunması inandırıcı olmayacaktır (Aktaş ve Gündüz, 2004, s. 21).

Okuma alışkanlığı kazanma ve bu alışkanlığı sürdürmeyi olumsuz yönde etkileyen önemli etkenlerden biri de teknolojik bağımlılıktır. Söz konusu teknolojilerin başında ise televizyon seyretme ve bilgisayar kullanımı gelmektedir. Bu konuda günümüze kadar yapılan araştırmaların çoğunda toplumun önemli bir kısmının 
dinlenme vakitlerinin önemli bir kısmını televizyon başında geçirdiği tespit edilmiştir (Aksaçlıoğlu ve Yılmaz, 2007, s. 9; Ortaş, 2007; Koçal, 2004). Televizyon özellikle okul öncesi dönemlerde çocukların zihinsel gelişimine katkıda bulunabilecek bir araçtır. Çocukların daha yaratıcı olmalarını ve dolayısıyla öğrenim becerilerinin gelişmesini sağlayan televizyon yayınları, aynı zamanda yetişkinlerin bilgi dağarcıklarını zenginleştirmeye yarayan özelliğe de sahiptir. Ancak izleme süresi ve izlenen programın türünde gerekli koşullar sağlanmadığı takdirde televizyon, özellikle çocuklar olmak üzere her yaştan insanın gelişimine, sosyal ilişkilerine ve sağlığına zararlı olabilecek bir araçtır. Gerek bazı yabancı ülkelerde gerekse Türkiye'de yapılan araştırmalar günlük televizyon izleme süresinin gereğinden fazla uzatıldığını göstermekte, bunun da insanın sağlığını, ilişkilerini ve günlük faaliyetlerini olumsuz yönde etkilediğini kanıtlamaktadır (Lehr, 1981, s. 231; Aksaçlıoğlu ve Yılmaz, 2007, s. 18; Televizyon, 2008). Televizyon ve İnternet başında üç saatten fazla vakit harcayan çocukların ilerleyen yaşlarda dikkat toplama sorunları yaşadıkları bilinmektedir. Yeni Zelandalı araştırmacılar bu duruma insan fizyolojisinin gereksinim duyduğu hareketli faaliyetlerin yerini ekran başında hareket yapmadan geçirilen uzun sürelerin neden olduğunu ileri sürmektedirler (îki, 2007).

Müzik, beden yorgunluğunun ruhsal dinginlikle hafifletilmesini sağlayan önemli bir araçtır. Ortamın atmosferine ve kişinin içinde bulunduğu ruh haline uygun dinlenen müziğin insan ruhunu rahatlatıcı bir yanı olduğu bilinen bir gerçektir. Ancak yaşamın vazgeçilmezlerinden biri olan müzik, insan yaşamına olumlu katkılar sağlayacak şekilde kullanılmalıdır. Yanlış uygulanması halinde müziğin konuya odaklanmanın zorunlu olduğu okuma eylemine iki açıdan zararı olmaktadır. Bunlardan ilki müzik için ayrılan vaktin okuma süresinin yerini alması, diğer bir ifade ile müzik dinleme isteminin okuma eyleminin ötelenmesine neden olmasıdır. Bu durum özellikle gençlerde daha yaygın görülmektedir. İkinci sorun ise müzik dinleyerek yapılan okumanın, müziğin bireyin eleştirel okuma yetisine baskın çıkmasına ve okunan konunun özüne tam olarak inilememesine yol açmasıdır (Aktaş ve Gündüz, 2004, s. 42). Özellikle gençler arasında müzik dinleyerek yapılan ders çalışma ya da okuma sürecinde müziğin o eyleme daha çok yoğunlaşma sağladığı 
gibi yanlış bir düşünce hâkimdir. Oysa dışarıdan alınan her uyarı gibi müzik sesi de, okuma ve anlama eylemine yoğunlaşmayı engelleyecek bir uyarı verir ve bireyin okuduğu metne odaklanmasını önleyerek eleştirel okuma ortamının bozulmasına neden olur.

Gelişmekte olan ülkelerin genel sorunlarından biri okuma kültürünün henüz belli bir olgunluk düzeyine ulaşamamış olmasıdır. $\mathrm{Bu}$ tür toplumlarda okuma alışkanlığı kazanılmasını engelleyen önemli bir etken de oyun oynama ve sohbet etme kültürünün okuma kültürüne baskın çıkmasıdır (Yulia, 2006; Darko-Ampem, 2004). Sangkaeo (1999) gelişmekte olan ülkelerde okuma alışkanlığının ve kütüphane kullanım oranının düşük olmasını benzer nedenlerle açıklamaktadır. Sangkao'ya göre söz konusu ülkelerdeki bu olumsuzluğun üç temel nedeni vardır: Bunlardan ilki gelişmekte olan toplumlarda dinleyerek öğrenme ve sohbet etme eğilimlerinin okuma etkinliğine ağır basmasıdır. İkinci etken, toplumun okuma alışkanlığına sahip bir toplum olmasında insan, para ve yönetim unsurlarından kaynaklanan olumsuzluklardır. Toplumun okuma alışkanlığı kazanmasında en önemli kuruluş olan kütüphanelerin sayıca az olması, kaynaklarının yeterli olmaması, eğitimli kütüphanecilere sahip olmaması ve gelişmiş hizmetler sunmak için yeterli bütçe ayrımaması bu sorunun altında yatan gerçekler olarak karşımızda durmaktadır. Öğrencilerin ve toplumun okuma alışkanlığı kazanabilmesi için okuma alışkanlığı geliştirme programları benzer nedenlere dayalı olarak oluşturulamamaktadır. Toplumun elektronik araç-gereçlere harcadıkları para ve emeğin okuma eyleminin önüne geçmesi ise üçüncü etken olarak değerlendirilmektedir.

\section{Türkiye'de Okuma Alışkanlığı}

Okuma ve kütüphane kullanımı bir toplumun gelişmişlik düzeyini yansıtan göstergelerden biri olarak kabul edilir. Kütüphane kullanım oranı konusunda somut bulguların elde edilmesi belli bir kitlenin okuma alışkanı olup olmadığının tespitinden daha kolaydır. Okuma alışkanlığı kişiden kişiye ve toplumdan topluma değişiklikler gösterir. Eğitim sistemi ve kurumları göz önüne alındığında okuma konusunda gelişmiş ülkelerin ulaştı̆̆ı düzeyin geri kalmış ülkeler için de ölçüt olarak alınması rasyonel bir sonuç veremez. Somut bir örnekle açıklanacak olursa, 1997 yılı verilerine göre Almanya'daki 
6.313 halk kütüphanesinde toplam 149.204 .798 kitap hizmete sunulmakta ve bu derme miktarına o yıl 7.028.733 kitap eklenmektedir. Buna karşılık 2006 yılı itibariyle Türkiye'de 1.179 halk kütüphanesinde hizmete sunulan toplam kitap sayısı 12.958.376'dır (Public, 2001; İstatistikler, 2008). Rakamlar iki ülke halkının okuma kültürü arasındaki farkı açıkça ortaya koymaktadır.

Bir toplumun ne düzeyde okuma alışkanlığına sahip olduğunu tespit edebilmek için iki göstergeden yararlanılabilir. Bu göstergelerden ilki doğrudan okuma alışkanlığının ölçülmesi amacıyla çocuklar, gençler ve yetişkinler üzerinde ayrı ayrı ya da tümünde birden yapılan gözlem, görüşme veya anket uygulamasından elde edilen sonuçlardır. Bu yöntemde hedef kitlenin okuma düzeyi daha önce yapılmış diğer çalışmalarla ya da okuma alışkanlığı konusunda oluşturulan standartlarla karşılaştıılarak tespit edilmeye çalışılır. İkinci yöntem ise okuma eylemi ile doğrudan ilişkili olan bir takım göstergelerden hareketle toplumun okuma düzeyini saptamadır. Örneğin ülkede üretilen/satın alınan kitap, dergi ve gazete miktarı, kütüphane sayısı, kütüphane kullanım istatistikleri, kütüphanelerin sahip olduğu koleksiyon miktarı ve türü gibi bazı ölçütler bunlardan bazılarıdır.

Türkiye'de okuma alışkanlık düzeyinin tespiti konusunda günümüze kadar gerek genel halk üzerinde gerekse öğrenciler, gençler ve öğretmenler gibi toplumun belli kesimi üzerinde çok sayıda çalışma yapılmıştır. Ancak bu çalışmaların çoğu birbirinden bağımsız yapılmıştır ve buna bağlı olarak belli bir kitle üzerinde yoğunlaşma söz konusudur ve bu çalışmaların düzenli aralıklarla tekrarı yapılamamıştır. Son on yıldır Türkiye'deki bütün yerleşim yerlerini, farklı etnik grupları, statüleri ve yaş gruplarını kapsayan bir çalışma yapılmamıştır. Buna karşın belli bir bölge, statü ve yaş grubu gibi farklı nitelikler üzerinde çok sayıda çalışma bulunmaktadır. Günümüze kadar yapılan çalışmaların hemen hepsinde Türk toplumunun okuma ve buna bağlı olarak kütüphane kullanma alışkanlığı oldukça zayıf çıkmıştır. 1990 yılında Kütüphaneler Genel Müdürlüğü tarafından yaptıılan 'Niçin az okuyoruz' adlı rapor bu çalışmalardan biridir. Rapor, okuma ve okuma eylemi ile ilişkili unsurların tespit edilmeye çalışıldığı anket uygulamasının bir sonucudur. 15 yaş üstü her yaş grubundan 1551 kişi üzerinde 
uygulanan anket sonuçlarına göre, Türk toplumunun okuma karnesi oldukça zayıf çıkmışır. Örneğin son bir ayda okunan kitap sayısının sorulduğu soruya katılımcıların \%40'ının hiç okumadığı ve \% 30'unun ise yalnızca bir kitap okuduğu belirlenmiştir. Aynı zamanda anket sonuçları katılımcıların \% 60'ının ebeveyninin kitap okumadıklarını, \% 51 'inin evlerinde kitaplık olmadığını, \% 41'inin bir hediye olarak yakınlarına kitap vermediğini ve yaklaşık \% 39'unun kütüphane kullanma alışkanlığına sahip olmadığını da göstermektedir (Özdemirci, 1990, ss. 154-155).

Okuma alışkanlığının tespiti konusunda başka bir araştırma 1989 yılında Hacettepe, Ankara ve İstanbul Üniversitelerinin kütüphanecilik bölümlerinde öğrenim gören 110 son sınıf öğrencisi üzerinde yapılmıştır. Bu çalışmada da halk kütüphanelerinden yararlanan katılımcıların yalnızca \% 3'te kalması, öğrencilerin okuma alışkanlığı düzeyini yansıtan en çarpıcı göstergelerden biridir (Sağlamtunç, 1990, s. 6). Yüksek öğretim öğrencilerinin okuma davranışını belirleme konusunda Hacettepe Üniversitesi Türk Dili ve Edebiyatı Bölümü son sınıf öğrencileri üzerinde yapılan diğer bir çalışmada ise, öğrencilerin yüksek öğrenim öncesi ve sonrasında okuma davranışları arasında çok az bir değişimin olduğunu ortaya koymaktadır (Ersoy, 2007, s. 182).

Benzer şekilde Yılmaz tarafından farklı yaş ve statü grupları üzerinde yapılan araştırmaların hemen hepsinde okuma ve kütüphane kullanımına ilişkin değerler oldukça düşük çıkmıştır. Ankara'da oturan 6 yaş üstü her yaş grubundan 1800 katıımcı üzerinde yapılan araştırmada, evli kişilerin yaklaşık \% 79'unun hiç okumadığı ya da çok az okuduğu görülmektedir. Yine bu çalışmada, babası okuryazar olmayan katılımcıların yaklaşık \% 84'ü hiç kitap okumazken, babası üniversite mezunu olanlarda bu oran sadece \% 10.3'tür (Yılmaz, 1995, s. 330). Aynı zamanda Yılmaz (2004, s. 121, 128, 129)'ın Ankara'nın çeşitli ilçelerindeki ilköğretim okulu beşinci sınıf öğrencileri üzerinde yaptığı başka bir araştırmada da öğrencilerin yaklaşık \% 70'inin ya hiç kitap okumadığı ya da yalnızca iki ayda bir kitap okuduğu belirlenmiştir. Aynı araştırmada, öğrencilerin annelerinin yaklaşık \% 50'si hiç kitap okumazken öğrencilerin yarısının kütüphaneye gitme alışkanlıklarının olmadığı görülmektedir. 
Aksaçlıoğlu ve Yılmaz (2007, s. 23)'ın yürüttükleri bir başka çalışmada ise ilköğretim okulu beşinci sınıf öğrencilerinin okuma alışkanlıkları ile bilgisayar ve televizyon arasındaki etkileşim ölçülmek istenmiştir. Söz konusu çalışmadan elde edilen bulgular, öğrencilerin bilgisayar kullanma ve televizyon izleme etkinliklerini kitap okumaya tercih ettikleri, televizyon ve bilgisayarın onların okumaya ayıracak zamanlarını azalttığı ve boş zaman etkinliği olarak okumayı diğer etkinliklere oranla daha az çekici bulduklarını göstermektedir.

Teknolojik cihaz kullanımının gereği olarak ya da iletişim için harcanan para miktarı, okuma ve bilinçlenmenin kaynağı olan yayın satın alımına yapılmamaktadır. Bu tür harcamalar daha çok genç nüfus içinde yaşanmaktadır. Örneğin Afyon Bolvadin'de 16-22 yaş grubundan 250 kişi üzerinde yapılan 'Gençler ne düşünüyor?' adlı anket çalışmasında, genç nüfusun aylık cep telefonu giderlerinin azımsanmayacak düzeyde olduğu görülmektedir. Elde edilen verilere göre Bolvadinli gençlerin yaklaşık yarısı ayda 50-100 kontör, yaklaşık \% 23'ü ise 200-250 kontör kullanmaktadır. Buna karşın aynı kitlenin düzenli gazete okuma alışkanlığı sadece \% 25 gibi düşük bir rakamda kalmaktadır (Gençler, 2008).

Daha önce ifade edildiği gibi belli bir insan grubunun okuma alışkanı olup olmadığını belirlemenin ikinci yolu söz konusu grubun okuma davranışına, kitap ve kütüphane kullanımına ilişkin birtakım istatistiksel verilerin elde edilmesidir. Örneğin kitap ve gazete tüketim oranı, kütüphane kullanımı ve kütüphanelerin sahip olduğu koleksiyon miktarı dikkate alınabilecek önemli ölçütlerdir. Türkiye'de basılan ve satılan kitap miktarı gelişmiş ülkelerle kıyaslanamayacak kadar düşük düzeydedir. UNESCO İstatistik Enstitüsü verilerine göre Almanya'da 1998 yılında üretilen kitap toplamı 78,042, İtalya'da 30,835 ve Polonya'da 16,646 iken Türkiye'de aynı yılda üretilen kitap sayısı 9313'tür. Üstelik 1995-1999 yılları arasında üretilen kitap ortalaması (6032) da daha küçüktür (Book, 2000).

Benzer bir durum UNESCO İstatistik Enstitüsünün yayınladığı kaynakta yer alan verilerde de görülmektedir. İngiltere'nin 1999 yılı verilerine göre 21,849 halk kütüphanesinde hizmete sunulan toplam kitap miktarı 121.752.000; 1997 yllında İtalya'daki 2155 kütüphanenin sahip olduğu toplam kitap sayısı 41.474.363'tür (Public, 2001). 
Buna karşın Kütüphaneler ve Yayımlar Genel Müdürlüğünün istatistiklerine göre 2006 yılında 1179 halk kütüphanesinde 12.958.376 kitap ile hizmet verilmektedir* (İstatistikler, 2008).

Bir ülkedeki okuma kültürünün niteliğini yansıtan önemli göstergelerinden biri de gazetelerin tirajıdır. Örneğin Dünya Gazeteciler Derneği (World Association of Newspaper)'nin istatistiğine göre 2005 yılında İngiltere'de günlük satılan ortalama gazete sayısı 17.375.000, Almanya'da 21.543.000'dir (World, 2006, s. II-160; World, 2005:380; Census, 2001). Türkiye'de ise 2008 yılı Mart ayı verilerine göre 38 ulusal gazetenin günlük satış ortalaması 5.127.928'dir (Rating, 2008; Adrese, 2007) (Bkz. Tablo 1).

Şüphesiz kitap, kütüphane ve okuma konuları ile doğrudan ilişkili verileri çoğaltmak mümkündür. Okuma kültürüne yapılan harcamalara karşın Türk toplumunda diğer keyfi tüketimin yüksekliği dikkat çekici boyuttadır. Örneğin Türk toplumunun önemli bir bölümü yüksek oranda sigara içmekte ve tüketilen sigaraya önemli miktarda harcama yapmaktadır. Ancak Türkiye'de sigara tüketimine harcanan bedel, kitap alımı için yapılan miktarın çok üzerine çıkmaktadır.

Tablo 1. Nüfus Bilgileri ve Gazete Satış Oranları

\begin{tabular}{|c|c|c|c|}
\hline \multicolumn{4}{|c|}{ Gazete Satış Oranları } \\
\hline Ülkeler & Toplam nüfus & Günlük satılan gazete & $\begin{array}{c}\text { Nüfusun gazete } \\
\text { satın alma oranı } \\
(\%)\end{array}$ \\
\hline Japonya & 126.688 .000 & $\begin{array}{r}107.000 .000 \\
(2004 \text { yılı) }\end{array}$ & 84,4 \\
\hline İngiltere & 58.789 .194 & $\begin{array}{r}17.375 .000 \\
(2005 \text { yılı) }\end{array}$ & 29,5 \\
\hline Almanya & 82.500 .800 & $\begin{array}{r}21.543 .000 \\
(2005 \text { yllı) }\end{array}$ & 26,1 \\
\hline Türkiye & 70.586 .256 & $\begin{array}{r}5.127 .928 \\
\text { (Mart 2008) }\end{array}$ & 7,26 \\
\hline
\end{tabular}

Örneğin Dünya Bankası'nın katkılarıyla hazırlanan Türkiye'de Tütün Ekonomisi adlı kaynağa göre 1990-1999 yılları arasında dünyadaki toplam sigara tüketimi \% 4,12 azalmasına rağmen, aynı dönemde Türkiye'de sigara tüketimi \% 52,18 artmıştır. Yine aynı kaynağa göre 2000 yılında her yetişkin Türk ortalama 134,65 paket

\footnotetext{
*Bazı halk kütüphanelerinin belediyelere devredilmesi nedeniyle 2003 yılında 1350 olan kütüphane sayısı 1179'a kadar düşmüştür.
} 
sigara tüketmiştir (Önder, 2002, s. 1). Buna karşın Türk halkının haftalık ortalama satın aldığı gazete miktarı 1999-2008 yılları arasında sadece \%25'lik artışla 4.050.000'den 5.100.000'e yükselmiştir (Haftalık, 1999; Rating, 2008).

Benzer şekilde kamu kuruluşlarına harcanan gider kalemleri de sigara tüketimi için harcanan miktarın oldukça altındadır. Örneğin 1993-2003 yılları arasında Türkiye'de halk kütüphanelerine alınan kitap oranında sadece \% 20'lik artı̧̧ yaşanmıştır. Ayrıca 1993 yılında 1092 halk kütüphanesinde 3718 personel hizmet verirken 2003 yilına kadar halk kütüphanesi sayısı 1350'ye yükselmiş, ancak personel sayısı 3134'e düşmüştür. Diğer bir ifade ile 1993-2003 yılları arasında halk kütüphanesi sayısında yaklaşık \% 22, toplam koleksiyon miktarında \% 24 artış olmasına rağmen, personel miktarında yaklaşık \% 16'lık kayıp yaşanmıştır (Türkiye, 2007a; Türkiye, 2007b).

Türkiye'de gerek okuma alışkanlığının belirlenmesi konusunda yapılan araştırmalara ve gerekse okuma, kitap ve kütüphane konuları ile doğrudan ilişkili olan göstergelere genel olarak bakıldığında Türk halkının önemli bir bölümünün,

- $\quad$ sürekli, düzenli ve eleştirel özelliklere sahip bir okuma kültürüne sahip olmadığı,

- buna bağlı olarak yeterli miktarda yayın satın almadığı ve

- okuma kültürünün geliştirilmesi konusunda son on yıldır önemli bir mesafe kaydedemediği görülmektedir.

Bununla birlikte Türk halkının sergilediği bu durum, kamu sisteminde de benzer şekilde kendini göstermektedir. Daha genel bir ifade ile Türkiye'de devlet, halkın okuma kültürünün arttırıması için kayda değer girişimlerde bulunmamış ve yatıımlar yapmamıştır.

\section{Araştırmanın Amacı ve Yöntemi}

Okumayı yaşamsal bir etkinlik olarak görüp sürekli ve düzenli olarak sürdürmek, bir toplumun gelişmişlik düzeyini yansıtan önemli bir göstergedir. Aynı zamanda kitaba sahip olma bilinci, evlerde kütüphane oluşturma eğilimi, kitap hediye etme alışkanlığı ve kütüphanelerden yararlanma düzeyi de bir ülkenin okuma etkinliğine verdiği önemi yansıtan diğer göstergelerdir. Türkiye gibi gelişmekte olan 
ülkelerde gençlerin okuma alışkanlığı kazanmaları, bilinçli ve gelişmiş bir toplum oluşturma yolunda atılacak önemli bir adımdır (Gönen, Öncü ve Işıtan, 2004). Türkiye'de okuma alışkanlığı konusunda günümüze kadar yapılan çalışmaların neredeyse tamamında Türk halkının okuma ve kütüphane kullanımı alışkanlıkları oldukça zayıf görünmektedir. Türk halkında yaşanan bu genel durumun üniversite öğrencileri üzerinde de benzer görünüme sahip olduğu hipotezinden hareketle, araştırmada ülkemizde üniversite öğrencilerinin okuma alışkanlığı profilinin saptanması amaçlanmaktadır. Bu doğrultuda ALA tarafından ortaya konan okur tipi ve günümüze kadar yapılan benzer nitelikli araştırmalarda sorgulanan okuma alışkanlığı ölçütleri çalışmanın temelini oluşturmaktadır. Araştırmanın bu temel üzerinde yapılması, sonuçların daha önce yapılan benzer araştırma sonuçlarıyla karşılaştırılabilmesi için gereklidir.

Çalışmada öğrencilerin cinsiyetinin, öğrenim gördükleri alanların, içinde bulunduğu ekonomik koşulların ve faaliyetlerin okuma alışkanlıklarına ne kadar etki ettiği belirlenmeye çalışılmıştır. Bu amaçla sosyal bilimler ve fen bilimlerinde öğrenim gören 304 öğrenciye anket uygulanmıştır. Katılımcıların 153'ü kız, 151'i ise erkek öğrencidir. Bu durum kız ve erkek öğrenciler arasında okuma alışkanlığı konusunda benzerlik ve farklılıkları ortaya koyma açısından önemlidir. Katılımcıların fen bilimlerinde öğretim gören 151 öğrenci matematik, fizik ve veterinerlik bölümlerinde; sosyal bilimler öğretim gören 153 öğrenci Alman dili, sosyoloji, felsefe ve bilgi ve belge yönetimi alanlarında öğrenim görmektedir. Bu durum, her iki grup öğrencilerin okuma alışkanlığında gözlemlenen benzerlik ve farklılıkları yansıtması açısından önemlidir. Katılımcıların yarısı birinci sınıf (152 öğrenci) diğer yarısı ise son sınıfta (151 öğrenci) yer almaktadır. Bu durum ise üniversite öğreniminin öğrencilerin okuma alışkanlığı ve kütüphane kullanımlarına hangi ölçüde etki ettiğini belirleyebilmek açısından önemlidir. Dolayısıyla çalışma genel olarak üniversite öğrencilerinin okuma alışkanlıkları ve becerileri ile kütüphane kullanımı eğilimlerini belirlemenin yanı sıra, öğrencilerin cinsiyetinin, öğrenim gördükleri alanların ve sınıf farklılıklarının okuma ve kütüphane kullanımı alışkanlıklarına ne düzeyde etki ettiğini de ortaya koyacaktır. 
Araştırmanın yapıldığı Ankara Üniversitesi lisans öğrencilerinin toplam sayısı $26.675^{\prime}$ tir. Anketlerin 0,95 güven ve 0,05 hoşgörü düzeyine göre lisans öğrencilerinin toplamını temsil eden örneklem miktarı 288 olmalıdır (Çıngı, 1990, s. 256). Anket sonuçları arasında boş bırakılanlar ya da hatalı olabilecekler göz önünde bulundurularak toplam 304 katılımcıya anket uygulanmış, sonuçlar SPSS (Statistical Package of Social Science) istatistik yazılımı ile değerlendirilmiştir. Anket formunun güvenilirliğini ölçmek için $F$ testi sonucunda bulunan alfa katsayısına bakılmıştır. Buna göre alfa değeri için $0.00 \leq \alpha<0.40$ aralığı güvenilir olmayan katsayı, $0.40 \leq \alpha<0.60$ aralığı düşük güvenilir katsayı, $0.60 \leq \alpha<0.80$ aralığı oldukça güvenilir katsayı ve $0.80 \leq \alpha<1.00$ aralığı ise yüksek derecede güvenilir katsayı anlamına gelmektedir (Özdamar, 1997, s. 500). Yapılan ölçümde alfa katsayısı 0.78 olarak bulunduğundan, anket formunun güvenilir olduğu kabul edilmiştir.

\section{Bulgular ve Değerlendirme}

$\mathrm{Bu}$ bölümde çalışmanın amacı doğrultusunda üniversite öğrencilerinin okuma kültürünü ortaya çıkarmak üzere hazırlanan ankete verilen cevapların analizi yapılmıştır. Anket alınan verilere göre katılımcıların cinsiyeti, sınıfı ve öğrenim gördüğü bilim dalına göre öğrencilerin okuma profilleri ortaya konulmuştur. Aynı zamanda öğrencilerin sosyo-ekonomik durumları ve ebeveynlerinin eğitim durumlarının okuma alışkanlığı kazanmalarına ne düzeyde etki yaptığı irdelenmiştir. Ayrıca özellikle gençlerin yaşantısında vazgeçilmezler arasında yer alan müzik, televizyon ve bilgisayarın okuma etkinliğinin yerini alıp almadığı sorgulanmıştır.

\section{Öğrencilerin Kitap Okuma Davranışları}

Anketin ilk sorularının yer aldığı bu bölümde, bir yıl içinde okudukları kitap sayısından hareketle öğrencilerin okuma alışkanlığı düzeyi belirlenmeye çalışılmaktadır. Okuma alışkanlığı düzeyi olarak Yılmaz'ın (2004, s. 120) ALA (1978, s. 3)'dan aldığı standart göz önünde bulundurulmuştur.

\footnotetext{
* Ankara Üniversitesi Bilgi İşlem Daire Başkanlığının hazırladığı strateji planından 20 Mart 2008 tarihinde alınan veridir.
} 
Bir yıl içinde okudukları toplam kitap sayısının tespit edilmek istendiği bir soruda öğrencilerin yarısı $(\% 46,1)$ en fazla beş kitap okuduğunu açıklarken, hiç kitap okumadığını belirten \%4,6'ık grupla birlikte öğrencilerin yaklaşık yarıya yakınının ya hiç kitap okumadığı ya da en fazla 5 kitap okuduğu anlaşımaktadır (Bkz. Tablo 2).

Tablo 2. Cinsiyete göre Öğrencilerin Bir Yılda Okudukları Kitap Sayısı

\begin{tabular}{lllllll}
\hline & \multicolumn{9}{c}{ Cinsiyet Türü } \\
\hline Okunan Kitap Sayısı & $\mathbf{N}$ & $\mathbf{K} \mathbf{z}$ & \multicolumn{3}{c}{ Erkek } & \multicolumn{2}{c}{ Toplam } \\
& $\mathbf{N}$ & $\mathbf{\%}$ & $\mathbf{N}$ & $\%$ & $\mathbf{N}$ & $\%$ \\
\hline Hiç & 4 & 2,6 & 10 & 6,6 & 14 & 4,6 \\
$6-11$ & 66 & 43,1 & 74 & 49,0 & 140 & 46,1 \\
12 'den çok & 67 & 43,8 & 50 & 33,1 & 117 & 38,5 \\
\hline Toplam & 16 & 10,5 & 17 & 11,3 & 33 & 10,9 \\
\hline & 153 & 100 & 151 & 100 & 304 & 100 \\
\hline
\end{tabular}

$\mathrm{Bu}$ değerler üniversite öğrencilerinin önemli bir bölümünün düşük okuma alışkanlığına sahip olduklarını göstermektedir. Tablo 2'de öğrencilerin sadece \% 10,9'unun üst düzey okuma alışkanlığı olduğu görülmektedir. Anketin uygulandığı yerin üniversite gibi okumayı özendiren bir eğitim kurumu olduğu göz önüne alındığında çıkan bu değerler oldukça düşündürücüdür. Ki-Kare testine göre bu tablonun değeri $P>.138$ olduğu için cinsiyet ile okunan kitap okuma oranı arasında anlamlı bir ilişki yoktur.

Kız ve erkek öğrenciler arasında da kitap okuma oranı açısından anlamlı bir fark bulunmamaktadır. Ancak yine de alt düzey ve orta düzey okuma alışkanlıklarında erkek ve kız öğrenciler arasında erkeklerin daha az okuduklarını gösteren bir ilişkinin varlığından söz edilebilir. Aynı zamanda bir yıl içinde hiç okumayan erkek öğrenciler kız öğrencilerden yarı yarıya fazladır (Bkz Tablo 2).

Tablo 3. Cinsiyete göre öğrencilerin günde ortalama kitap okuma eylemine ayırdıkları süre

\begin{tabular}{|c|c|c|c|c|c|c|}
\hline \multirow{3}{*}{$\begin{array}{l}\text { Günlük Okuma } \\
\text { süreleri }\end{array}$} & \multicolumn{4}{|c|}{ Cinsiyet Türü } & \multirow{2}{*}{\multicolumn{2}{|c|}{ Toplam }} \\
\hline & \multicolumn{2}{|c|}{$\mathbf{K} \mathbf{z z}$} & \multicolumn{2}{|c|}{ Erkek } & & \\
\hline & $\mathbf{N}$ & $\%$ & $\mathbf{N}$ & $\%$ & $\mathbf{N}$ & $\%$ \\
\hline $0-0,5$ saat & 15 & 9,8 & 25 & 16,6 & 40 & 13,2 \\
\hline $0,5-0,9$ saat & 50 & 32,7 & 64 & 42,4 & 114 & 37,5 \\
\hline $1-1,9$ saat & 63 & 41,2 & 44 & 29,1 & 107 & 35,2 \\
\hline 2 saatten çok & 25 & 16,3 & 18 & 11,9 & 43 & 14,1 \\
\hline Toplam & 153 & 100 & 151 & 100 & 304 & 100 \\
\hline
\end{tabular}


Okuma alışkanı birey, okumaya her gün belli oranda zaman ayıran kişidir. Genele oranla üniversite öğrencileri bir toplumun en üst düzeyde okuma kültürüne sahip grubu içinde yer almalıdır. Tablo 3'te öğrencilerin okuma eylemine günlük ortalama ayırdıkları süreler gösterilmektedir. Buna göre düşük okuma düzeyi olarak tanımlanabilecek 0-0,5 saatlik dilimde erkek öğrencilerin $(\% 16,6) \mathrm{kIz}$ öğrencilere $(\% 9,8)$ göre daha fazla görülmektedir. Buna karşın orta üstü ve üst okuma sürelerini gösteren 1-1,9 saat ve 2 saatten fazla seçeneklerini işaretleyenler arasında ise kız öğrenciler erkeklerden daha fazladır. Genel toplamı gösteren rakamlara bakıldığında ise günlük okuma süresi konusunda öğrencilerin yaklaşık yarısının alt ve orta altı okuma düzeyine sahip olduğu görülmektedir. Bu sonuçlara göre üniversite öğrencilerinin okuma eylemine yeterince zaman ayırdıklarını söylemek güçtür.

Tablo 4. Bilim alanına göre öğrencilerin ortalama kitap okuma eylemine ayırdıkları süre

\begin{tabular}{lcccc}
\hline & \multicolumn{4}{c}{ Okuma Süresi } \\
\hline $\begin{array}{l}\text { Günlük Okuma } \\
\text { süreleri }\end{array}$ & $\mathbf{0 - 0 , 5}$ saat & $\mathbf{0 , 6 - 0 , 9}$ saat & $\mathbf{1 - 1 , 9}$ saat & $\begin{array}{c}\text { 2 saat ve } \\
\text { üstü } \\
\mathbf{\%}\end{array}$ \\
\hline Fen Bilimleri & $\%$ & $\mathbf{\%}$ & $\mathbf{\%}$ & 9,9 \\
Sosyal Bilimler & 16,6 & 41,1 & 32,5 & 9,9 \\
\hline Toplam & 9,8 & 34,0 & 37,9 & 18,3 \\
\hline
\end{tabular}

Tablo 4'te fen ve sosyal bilimlere göre öğrencilerin bir gün içinde okuma etkinliğine ayırdığı süreye ilişkin veriler yer almaktadır. Veriler okuma süresi ortalamasının altında yoğun olarak fen bilimi öğrencilerinin yer aldığını, buna karşın okuma ortalamasının üstünde ise daha çok sosyal bilimler öğrencilerinin yer aldığını göstermektedir. Buna göre sosyal bilimler alanında eğitim gören öğrencileri okuma eylemine daha uzun süre ayırmaktadırlar.

Üniversite eğitimi bireyin yalnızca öğrenim gördüğü alanda uzmanlaşmasını değil, aynı zamanda yaşam ve genel kültür bilincinin artmasını, ruhsal ve davranışsal olgunluk kazanmasını sağlayan önemli bir eğitim sürecidir. Bu süreç, üniversite hayatının ilk yıllarından itibaren öğrencilerin yaşam kalitelerini arttırmaya yönelik davranışları kazanmalarıyla başlar ve söz konusu sürecin son noktasına kadar devam eder. Okuma alışkanlığı, küçük 
yaşlarda kazanılan ve eğitim hayatı içinde geliştirilen bir yaşam standardıdır. Üniversite öğrenim sistemi de öğrencilerin okuma kültürünü geliştirecek uygun bir ortamdır.

Tablo 5. Sınıflarına göre öğrencilerin bir yılda okuduğu kitap sayısı

\begin{tabular}{lcccccc}
\hline Okunan kitap & \multicolumn{2}{c}{ Birinci sınıf } & \multicolumn{2}{c}{ Son sınıf } & \multicolumn{2}{c}{ Toplam } \\
sayısı & $\mathbf{N}$ & $\boldsymbol{\%}$ & $\mathbf{N}$ & $\%$ & \multicolumn{1}{c}{$\mathbf{N}$} & $\%$ \\
\hline Hiç & 6 & 3,9 & 8 & 5,3 & 14 & 4,6 \\
$1-5$ & 77 & 50,7 & 63 & 41,7 & 140 & 46,1 \\
6-11 & 54 & 35,5 & 62 & 41,1 & 116 & 38,5 \\
12'den çok & 15 & 9,9 & 18 & 11,9 & 33 & 10,9 \\
\hline Toplam & 152 & 100 & 151 & 100 & 303 & 100 \\
\hline
\end{tabular}

Tablo 5'te ilk ve son sınıf öğrencilerinin okuma alışkanlığı konusunda sahip oldukları durumları gösteren veriler yer almaktadır. Buna göre bir yıl içinde okudukları kitap toplamının sorulduğu soruya birinci sınıf öğrencilerinin \% 50,7'si 1-5 kitap cevabını vermiştir. Düşük okuma göstergesi olarak kabul edilen 1-5 kitap aralığı son sınıf öğrencilerinde yaklaşık \% 8'lik bir düşüş ile \% 41,7 olarak belirlenmiştir. Buna karşın birinci sınıf öğrencileri \% 35,5'lik bir oranla orta düzey okuma göstergesi olan bir yılda 6-11 kitap aralığında yoğunlaşırken, bu oranın dördüncü sınıf öğrencilerinde \%41,1'e yükseldiği görülmektedir. Bu iki veri düşük okuma alışkanlığına sahip birinci sınıf öğrencilerinin son sınıfa geldiklerinde az da olsa orta düzey okuma alışkanlığına sahip bireylere dönüştüğünü göstermektedir. Hiç kitap okumayan ve üst düzey okuma alışkanlığına sahip öğrenciler arasında ise önemli bir değişikliğin yaşanmadığı görülmektedir. Tabloda sergilenen genel durum göz önüne alındığında ise öğrencilerin üniversite öğrenim hayatları boyunca okuma alışkanlıklarını geliştirme konusunda önemli bir ilerleme kaydedemedikleri söylenebilir.

Okuma alışkanlığı kazanmada ve bu alışkanlığı hayatın tüm evreleri boyunca sürdürmede bireyin kendi çabasına duyulan gereksinim kadar içinde bulunduğu çevrenin katkısı da önemlidir. Birey, içinde bulunduğu çevresel koşullara göre okuma alışkanlığı konusunda teşvik edilir ya da engellenir. Okuma alışkanlığının kazanılmasını, sürdürülmesini ve geliştirilmesini engelleyen faktörler bireyin içinde bulunduğu çevreye göre değişiklik gösterir. Örneğin düşük gelirli bir ailede, aile fertlerinin daha çok fiziksel doyum 
amacıyla maddi kazanıma yönlenmesi, çalışma yoğunluğunun okuma eyleminin önüne geçmesine ve okumanın ötelenmesine neden olur. Benzer şekilde gereğinden fazla televizyon izleyen bir bireyin okuma alışkanlığı kazanma ve bu davranışı geliştirme konusunda başarı elde etme şansı zayıftır.

Anketin bir başka sorusunda okuma alışkanlığı kazanma ve bu alışkanlığı sürdürme konusunda karşı karşıya kaldıkları en önemli engelin ne olduğu sorulmuş ve öğrencilerin önemli bir kısmı $(\%$ 34,4) bir işte çalışıyor olmaları nedeniyle okuyamadıklarını belirtmiştir (Bkz. Tablo 6).

Tablo 6. Cinsiyete göre öğrencilerin okumasına engel olan nedenler

\begin{tabular}{|c|c|c|c|c|c|c|}
\hline \multirow{3}{*}{$\begin{array}{l}\text { Okumaya engel olan } \\
\text { faktörler }\end{array}$} & \multicolumn{4}{|c|}{ Cinsiyet Türü } & \multirow{2}{*}{\multicolumn{2}{|c|}{ Toplam }} \\
\hline & \multicolumn{2}{|c|}{ KIz } & \multicolumn{2}{|c|}{ Erkek } & & \\
\hline & $\mathbf{N}$ & $\%$ & $\mathbf{N}$ & $\%$ & $\mathbf{N}$ & $\%$ \\
\hline Cevap yok & 3 & 2,0 & 1 & 0,7 & 4 & 1,3 \\
\hline Ekonomik $^{*}$ & 15 & 9,8 & 30 & 19,9 & 45 & 14,8 \\
\hline Kültürel $^{* *}$ & 6 & 3,9 & 6 & 4,0 & 12 & 3,9 \\
\hline Eğitimsel $^{* * *}$ & 24 & 15,7 & 21 & 13,9 & 45 & 14,8 \\
\hline Çalışma yoğunluğu ${ }^{* \star *}$ & 61 & 39,9 & 52 & 34,4 & 113 & 37,2 \\
\hline Gezi-eğlence & 44 & 28,8 & 41 & 27,2 & 85 & 28,0 \\
\hline Toplam & 153 & 100 & 151 & 100 & 304 & 100 \\
\hline
\end{tabular}

Kitap pahalılığı ve gelir düşüklüğü nedeniyle okumalarına engel olarak ekonomik koşulları ileri süren öğrencilerin oranı ise \%14,8'dir. Ekonomik koşullar ve çalışma yoğunluğu nedeniyle okuyamadıklarını ileri süren öğrencilerin toplamı yaklaşık \% 53 gibi önemli bir oranı oluşturmaktadır. Ancak Tablo 8'deki alt ve orta altı gelirli öğrencilerin bir yılda okudukları kitap sayısının düşük okuma düzeyinin üst gelirli öğrencilerde yüksek; orta okuma düzeyinin de alt gelirli öğrencilerde yüksek çıkması; üst okuma düzeyinin ise hem alt hem de üst gelirlilerde eşit olması, öğrencilerin okumaya engel olarak gösterdikleri ekonomik koşulları geçersiz kılmaktadır. Daha sonraki tablolarda görüleceği gibi, öğrencilerin okumalarına engel olan en önemli faktör bir araya gelme ve eğlenme arzularının okuma

\footnotetext{
" Kitap fiyatlarının yüksek oluşu ve gelir düşüklügü

"..Aile ve toplum baskısı, çevrenin iyi örnek olmaması

.... Eğitim sisteminin okuma bilincini verememesi

Herhangi bir işte çalışma

Televizyon izleme, sinemaya gitme, müzik dinleme, internette dolaşma, oyun oynama
} 
eylemine baskın çıkmasıdır. Tablo 6'da görüldüğü gibi sinemaya gitme, televizyon seyretme, müzik dinleme, internette gezinme ve arkadaşlarla sohbet etme eylemlerinden oluşan gezi ve eğlence gerekçesine verilen yanıt oranı \% 28 'dir.

\section{Öğrencilerin okuma alışkanlığı kazanmalarında ebeveynin ve sosyo-ekonomik koşulların rolü}

Bireyin yaşam için gerekli becerileri kazanması sürecinde ebeveyne düşen önemli roller vardır. Okuma alışkanlığı da ebeveynin teşviki ve model olarak alınması ile kazanılabilecek bir beceridir. Günümüze kadar yapılan araştırmaların çoğu okuma kültürünün olmadığı ailelerde çocukların bu beceriye yeterli düzeyde sahip olamadıklarını ve yaşamları boyunca düzenli olarak sürdüremediklerini göstermektedir (Yılmaz, 2004, ss. 127-128; Sağlamtunç, 1990, ss. 8-9). Sorunun temelinde ebeveynin eğitim düzeyi yatmaktadır. Daha açık bir ifade ile yüksek eğitimli ebeveynin çocukları okumaya daha fazla eğilim göstermektedir.

Eğitim düzeyi yüksek olan annelerin okuma alışkanlığı kazanmaları konusunda çocukları üzerinde etkili olduğu, annelerin eğitim düzeyi yükseldikçe kitap okuma eğilimlerinin arttığı Tablo 7 'deki verilerden görülebilmektedir. Bir yıl içinde hiç kitap okumayan ve alt düzeyde kitap okuyan (1-5 kitap) öğrencilerin en çok bulunduğu grubun (\% 64,5) anneleri ilkokul mezunu ya da terk etmiş olanlardan oluşmaktadır. Bu oranın daha eğitimli annelerde düştüğü, örneğin anneleri üniversite mezunu olan kişilerde yoğunluğun orta düzeyli okur tipinde olduğu görülmektedir.

Tablo 7. Annelerin eğitim düzeyine göre öğrencilerin kitap okuma alışkanlıkları

\begin{tabular}{|c|c|c|c|c|c|c|c|c|}
\hline \multirow{3}{*}{$\begin{array}{l}\text { Okunan } \\
\text { kitap sayısı }\end{array}$} & \multicolumn{6}{|c|}{ Annelerin eğitim düzeyi } & \multirow{2}{*}{\multicolumn{2}{|c|}{ Toplan }} \\
\hline & \multicolumn{2}{|c|}{ İlköğretim } & \multicolumn{2}{|c|}{ Ortaöğretim } & \multicolumn{2}{|c|}{ Üniversite } & & \\
\hline & $\mathbf{N}$ & $\%$ & $\mathbf{N}$ & $\%$ & $\mathbf{N}$ & $\%$ & $\mathbf{N}$ & $\%$ \\
\hline Hiç & 8 & 5,3 & 5 & 3,7 & 1 & 5,0 & 14 & 4,6 \\
\hline $1-5$ & 90 & 59,2 & 43 & 32,6 & 5 & 25,0 & 138 & 46,1 \\
\hline $6-11$ & 45 & 29,6 & 57 & 46 & 12 & 60,0 & 114 & 38,5 \\
\hline 12'den çok & 9 & 5,9 & 22 & 17,6 & 2 & 10,0 & 33 & 10,9 \\
\hline Toplam & 152 & 100 & 110 & 100 & 20 & 100 & 299 & 100 \\
\hline
\end{tabular}


Tablo 8. Babaların eğitim düzeyine göre öğrencilerin kitap okuma alışkanlıkları

\begin{tabular}{lcccccccc}
\hline \multicolumn{10}{c}{ Babaların eğitim düzeyi } \\
\hline $\begin{array}{l}\text { Okunan } \\
\text { kitap sayısı }\end{array}$ & \multicolumn{1}{c}{ İlköğretim } & \multicolumn{2}{c}{ Ortaöğretim } & \multicolumn{2}{c}{ Üniversite } & \multicolumn{2}{c}{ Toplam } \\
\hline Hiç & 0 & $\mathbf{N}$ & $\mathbf{N}$ & $\mathbf{N}$ & $\%$ & $\mathbf{N}$ & $\%$ \\
$1-5$ & 0 & 0 & 12 & 4,6 & 2 & 3,3 & 14 & 4,6 \\
$6-11$ & 5 & 50,0 & 122 & 49,7 & 13 & 21,7 & 140 & 46,1 \\
12 'den çok & 1 & 10,0 & 16 & 7,6 & 16 & 26,7 & 33 & 10,9 \\
\hline Toplam & 10 & 100 & 233 & 100 & 60 & 100 & 303 & 100 \\
\hline
\end{tabular}

Benzer durum, babaların eğitim düzeyinin çocukların okuma alışkanlığına yansımasının gösterildiği Tablo 8'de de görülmektedir. Tabloya göre ağırlıklı olarak 1-5 kitap seçeneğini işaretleyenler, babaları ilköğretim mezunu ya da terk etmiş (\% 50) ve ortaöğretim mezunu olan (\% 59,7) öğrencilerden oluşmaktadır. Babaları ilköğretimden mezun olmuş ya da ayrılmış öğrenciler çoğunlukla düşük okuma alışkanı birey grubuna dâhildir. Benzer durum ortaöğretim mezunu babaların çocuklarında da görülmektedir. Buna göre ortaöğretim mezunu babaların çocuklarının \% 4,6'sı son bir yılda hiç kitap okumadığını belirtmektedir. Aynı grup içinde bir yılda 1-5 kitap okuyanlar \% 49,7'lik oranı, 6-11 kitap okuyanlar \% 38,1'lik oranı ve 12 kitaptan çok okuyanlar ise \% 7,6'lık oranı temsil etmektedirler. Verilerden görüldüğü gibi düşük okuma düzeyinden yükseğe doğru ters bir orantı söz konusudur. Eğitim düzeyi ilköğretimden üniversiteye doğru yükseldikçe yılda 12'den fazla kitap okuyan öğrencilerin oranının \% 10'dan \% 26,7'ye yükselmesi okuma alışkanlığı kazanma konusunda babaların eğitim düzeyinin ne denli önemli olduğuna işaret etmektedir.

Ayrıca anne ve babaların eğitim durumlarına ilişkin veriler (Bkz. Tablo 7, Tablo 8) karşılaştırıldığında her iki durumun öğrenciler üzerinde belirgin bir farklılığa neden olmadığı görülmektedir.

Bireyin içinde bulunduğu sosyo-ekonomik koşullar gündelik yaşamda önceliklerin kişiden kişiye farklılaşmasına neden olur. Bireyin içinde bulunduğu ortam okumayı ve kişisel gelişimi teşvik edecek koşullara sahip olabilir. Okuma ve kütüphane kullanma kültürü kazanmış arkadaş grubunun çevresi ile etkileşimde bulunması 
buna örnek olarak gösterilebilir. Buna karşın içinde bulunulan ekonomik koşullar bireyler arasında okuma konusunda derin farkların oluşmasına neden olamaz. Çünkü gelir seviyesi düşük olan bireylerin içinde bulunduğumuz dönemde bu gereksinimi karşılamak için yararlanabileceği koşullar sağlanmış bulunmaktadır. Günümüze kadar yapılan araştırmaların çoğu da bu görüşü destekler niteliktedir.

Tablo 9, öğrencilerin bulundukları sosyo-ekonomik koşulların kitap okuma davranışlarına ne düzeyde etki ettiğini gösteren veriler içermektedir. Kendini sosyo-ekonomik bakımdan alt düzeyde tanımlayan öğrenciler arasında yıl içinde kitap okumayan öğrenci bulunmamasına karşın orta altı, orta üstü ve üst düzey sosyo-ekonomik koşullara sahip öğrenceler arasında hiç kitap okumayan kişi sayısın var olduğu görülmektedir. Benzer şekilde düşük okuma alışkanlığı düzeyini temsil eden 1-5 kitap aralığı daha çok sosyo-ekonomik bakımdan üst sıralarda yer alan öğrenciler tarafından işaretlenmiştir.

Tablo 9. Sosyo-ekonomik koşullara göre öğrencilerin okudukları kitap sayısı

\begin{tabular}{lccccccccccc}
\hline & \multicolumn{1}{c}{ Katılımcıların Sosyo-Ekonomik Durumları } \\
\hline $\begin{array}{l}\text { Okunan kitap } \\
\text { sayısı }\end{array}$ & $\mathbf{N}$ & Alt & \multicolumn{3}{c}{ Orta Altı } & $\mathbf{N}$ & $\%$ & \multicolumn{2}{c}{ Orta Üstü } & \multicolumn{3}{c}{ Üst } & \multicolumn{3}{c}{ Toplam } \\
\hline Hiç & 0 & 0 & 7 & 3,8 & 6 & 6,4 & 1 & 11,1 & 14 & 4,6 \\
$1-5$ & 7 & 46,7 & 79 & 42,9 & 49 & 52,1 & 5 & 55,6 & 140 & 46,1 \\
$6-11$ & 6 & 40,0 & 81 & 44,0 & 26 & 27,7 & 2 & 22,2 & 115 & 38,5 \\
12 'den çok & 2 & 13,3 & 17 & 9,2 & 13 & 13,8 & 1 & 11,1 & 33 & 10,9 \\
\hline Toplam & 15 & 100 & 184 & 100 & 94 & 100 & 9 & 100 & 302 & 100 \\
\hline
\end{tabular}

Sosyo-ekonomik bakımdan orta üstü ve üst sıralarda yer alan öğrencilerin 6 ve üzeri kitap okuyanların orta altı sosyo-ekonomik düzeyli öğrencilerden daha düşük bir okuma alışkanlığına sahip olması dikkate değer bir durumdur. 12'den çok kitap okuyan öğrenci grubuna bakıldığında ise sosyo-ekonomik bakımdan alt ve üst sıralarda yer alan öğrencilerin sosyo-ekonomik bakımdan orta altı ve orta üstü gruba göre oldukça düşük okuma yüzdesine $(\% 11,1)$ sahip olduğu görülmektedir. Ancak alt ve üst gelir grubunun oldukça yakın değerlere sahip olması okuma davranışı konusunda sosyoekonomik koşulların öğrenciler arasında derin bir farka neden olmadığını göstermektedir. Örneğin çok okuyan okur grubunda alt gelirli öğrenciler \% 13,3 iken, bu oran üst gelirli öğrencilerde \% 11,1'dir. 


\section{Öğrencilerin kütüphane kullanımı konusunda sergiledikleri tutum}

Üniversite kütüphaneleri, üniversitenin bütün paydaşlarının bilgi gereksinimini karşılayabilecek niteliğe sahip olmalıdır. Aynı zamanda üniversite kütüphanesi öğrencilerin okuma alışkanlıklarını destekleyecek ve geliştirecek dermeye ve programlara da sahip olmalıdır. Okuma alışkanlığı üniversite kütüphanelerinde özellikle danışma hizmeti biriminin öncülüğünde desteklenmelidir. Öğrenciler sürekli olarak yeni ve popüler yayınlar konusunda bilgilendirilmeli ve ilgi duydukları konular için doğru kaynaklara yönlendirilmelidir. Aynı zamanda öğrencilerin okuma istemi zengin dergi ve gazete aboneliği ile de desteklenmelidir (Elliot, 2007, s. 34, 37). Kütüphane kullanımı bir ölçüde bireyin okumaya ne ölçüde önem verdiğini belirleyen göstergelerden biridir.

Tablo 10. Cinsiyete göre öğrencilerin kütüphane kullanım oranı

\begin{tabular}{|c|c|c|c|c|c|c|}
\hline \multicolumn{7}{|c|}{ Cinsiyet Türü } \\
\hline \multirow[t]{2}{*}{ Kullanım sıklığı } & \multicolumn{2}{|c|}{ Kız } & \multicolumn{2}{|c|}{ Erkek } & \multicolumn{2}{|c|}{ Toplam } \\
\hline & $\mathbf{N}$ & $\%$ & $\mathbf{N}$ & $\%$ & $\mathbf{N}$ & $\%$ \\
\hline Hemen her gün & 7 & 4,6 & 3 & 2,0 & $\overline{10}$ & $\overline{3,3}$ \\
\hline Her hafta & 26 & 17,0 & 21 & 13,9 & 47 & 15,5 \\
\hline Her ay & 25 & 16,3 & 23 & 15,2 & 48 & 15,8 \\
\hline Nadiren & 94 & 61,4 & 100 & 66,2 & 194 & 63,8 \\
\hline Toplam & 152 & 99,3 & 147 & 97,4 & 299 & 98,4 \\
\hline
\end{tabular}

Anket uygulanan öğrencilerin kütüphaneden ne sıklıkla yararlandıklarını gösteren veriler Tablo 10 'da yer almaktadır. Tabloya göre üniversite öğrencilerinin sadece \% 3,3'ü her gün, \% 15,5 'i her hafta ve \% 15,8'i de her ay kütüphaneden yararlandıklarını belirtmektedirler. Tablonun en dikkate değer kısmı ise öğrencilerin \% 63,8'lik bölümünün kütüphaneden nadiren yararlandıklarını belirtmesidir. Diğer bir ifade ile üniversitede kütüphaneye gitmeyen önemli bir öğrenci kitlesi bulunmakta ve bunlar kütüphaneye gitmeme nedenini kütüphaneden hoşlanmama ile açıklamaktadır. Elde edilen sonuçlar üniversitelerde kütüphane hizmetlerinin sorgulanması gerektiğine işaret etmektedir.

Öğrencilerin kütüphane kullanım oranları ve kütüphanelerden ödünç aldıkları kitap sayıları da okuma alışkanlığının tespit edilmesinde yararlanılabilecek göstergelerden biridir. Bu nedenle 
ankette öğrencilerin bir yıl içinde kütüphaneden ödünç aldıkları kitap sayıları sorgulanmakta ve söz konusu sayıların cinsiyete göre dağılımı Tablo 11'de verilmektedir.

Tablo 11. Cinsiyete göre öğrencilerin bir yılda kütüphanelerden ödünç aldıkları kitap sayıları

\begin{tabular}{|c|c|c|c|c|c|c|}
\hline \multicolumn{7}{|c|}{ Cinsiyet Türü } \\
\hline Kütüphaneden & \multicolumn{2}{|c|}{$\mathrm{K} \mathbf{} \mathbf{z}$} & \multicolumn{2}{|c|}{ Erkek } & \multicolumn{2}{|c|}{ Toplam } \\
\hline $\begin{array}{l}\text { ödünç alınan } \\
\text { kitap sayısı }\end{array}$ & $\mathbf{N}$ & $\%$ & $\mathbf{N}$ & $\%$ & $\mathbf{N}$ & $\%$ \\
\hline 0-3 kitap & 104 & 68,0 & 117 & 77,5 & 221 & 72,7 \\
\hline 4-15 kitap & 32 & 20,9 & 22 & 14,6 & 54 & 17,8 \\
\hline 16'dan çok kitap & 2 & 1,3 & 2 & 1,3 & 4 & 1,3 \\
\hline Toplam & 138 & 91,2 & 141 & 93,4 & 279 & 91,8 \\
\hline
\end{tabular}

Öğrencilerin kütüphanelerden yeterince yararlanmadıkları Tablo 11'deki verilerden anlaşılmaktadır. Tabloya göre öğrencilerin önemli bir bölümü (\% 72,7) kütüphaneden yılda en fazla 3 kitap ödünç aldıklarını ifade etmektedir. Kütüphane kaynaklarından yararlanma oranı kız öğrencilerde biraz daha yüksek olsa da toplamda üniversite öğrencilerinin kütüphane kullanma alışkanlığına sahip olmadığı görülebilmektedir.

Tablo 12'de öğrencilerin kütüphanelerden ne derece memnun olduklarını gösteren veriler yer almaktadır. Tablodan elde edilen bulgular aynı zamanda öğrencilerin kütüphaneye gitmeme ya da kütüphane hizmetinden yararlanmama nedenlerini de açıklayacak yargılar içermektedir.

Tablo 12. Cinsiyete göre öğrencilerin kütüphane memnuniyeti düzeyi

\begin{tabular}{|c|c|c|c|c|c|c|}
\hline \multicolumn{7}{|c|}{ Cinsiyet Türü } \\
\hline \multirow{2}{*}{$\begin{array}{l}\text { ‘Kütüphaneye } \\
\text { gitmekten zevk } \\
\text { alıyorum' ifadesine } \\
\text { verilen yanıtlar }\end{array}$} & \multicolumn{2}{|c|}{ Kız } & \multicolumn{2}{|c|}{ Erkek } & \multicolumn{2}{|c|}{ Toplam } \\
\hline & $\mathbf{N}$ & $\%$ & $\mathbf{N}$ & $\%$ & $\mathbf{N}$ & $\%$ \\
\hline $\begin{array}{l}\text { Tamamen } \\
\text { katılıyorum }\end{array}$ & 22 & 14,4 & 16 & 10,6 & 38 & 12,5 \\
\hline Katılıyorum & 42 & 27,5 & 40 & 26,5 & 82 & 27,0 \\
\hline Fikrim yok & 33 & 21,6 & 35 & 23,2 & 68 & 22,4 \\
\hline Katılmıyorum & 31 & 20,3 & 35 & 23,2 & 66 & 21,7 \\
\hline $\begin{array}{l}\text { Kesinlikle } \\
\text { katılmıyorum }\end{array}$ & 18 & 11,8 & 16 & 10,6 & 34 & 11,2 \\
\hline Toplam & 146 & 95,4 & 147 & 94 & 288 & 94,7 \\
\hline
\end{tabular}


Kütüphane memnuniyetinin belirlenmeye çalışıldığı bir soruya öğrencilerin yaklaşık \% 40'ı kütüphaneye gitmekten zevk aldığını buna karşın \% 33'ü kütüphane kullanımından zevk almadığını bildirmektedir. Bununla birlikte kızların yaklaşık \% 42'si kütüphaneye gitmekten zevk aldığını ifade ederken bu oran erkek öğrencilerde yaklaşık \% 5 daha düşüktür. Önemli bir fark olmasa da tabloya göre erkeklerin kütüphane kullanımı konusunda kızlara oranla daha isteksiz oldukları görülmektedir. Katılımcıların yaklaşık \% 40'ı kütüphaneye gitmekten zevk duyduklarını ifade etseler de Tablo 10 ve Tablo 11'deki veriler keyif duydukları bu ortamı yeterince kullanmadıklarını göstermektedir.

Tablo 13'te öğrencilerin kütüphaneye gitmekten memnun olma düzeyleri ile kütüphaneyi ziyaret etme sıklıkları karşılaştırılmaktadır. Tabloda kütüphaneye gitmekten oldukça memnun olduğunu söyleyen öğrencilerin önemli bir kısmının aslında kütüphaneye nadiren uğradığı görülmektedir. Kütüphaneye gitmekten memnun olmadıklarını belirten öğrenciler ise ayda bir kere ya da nadiren şıklarına verdikleri yanıtlarla ifadelerini pekiştirmektedirler.

Tablo 13. Kütüphane ziyaretine göre kütüphane memnuniyeti

\begin{tabular}{lcccc}
\hline & \multicolumn{3}{c}{ Kütüphane Kullanım Sıklığı } \\
\hline $\begin{array}{l}\text { ‘Kütüphaneye gitmekten zevk } \\
\text { alıyorum' ifadesine verilen yanıtlar }\end{array}$ & $\begin{array}{c}\text { Her gün } \\
\%\end{array}$ & $\begin{array}{c}\text { Her hafta } \\
\%\end{array}$ & $\begin{array}{c}\text { Her ay } \\
\%\end{array}$ & $\begin{array}{c}\text { Nadiren } \\
\%\end{array}$ \\
\hline Tamamen katılıyorum & 15,8 & 28,9 & 13,2 & 42,1 \\
Katılıyorum & 2,4 & 22,0 & 26,8 & 47,6 \\
Çekimserim & 1,5 & 7,4 & 11,8 & 77,9 \\
Katılmıyorum & 1,5 & 12,1 & 9,1 & 77,3 \\
Kesinlikle katılmıyorum & 0 & 14,7 & 14,7 & 70,6 \\
\hline Ortalama & 3,3 & 15,8 & 15,5 & 63,8 \\
\hline
\end{tabular}

Araştırmada öğrencilerin kütüphaneden memnuniyet düzeyini belirleyebilmek için elde edilen veriler, fen ve sosyal bilimler arasında da karşılaştııılmaktadır (Bkz. Tablo 14). Öğrenimini sosyal bilimlerde sürdüren öğrencilerin, uygulama çalışmalarının ağırlıkta olduğu fen bilimlerine oranla okuma eylemine daha fazla zaman ayırması olağan bir durumdur. Teorik öğreti metodunun ağırlıkta olduğu sosyal bilimlerde eğitimin önemli bir bölümü okumaya dayalı olarak sürdürülür. $\mathrm{Bu}$ nedenle sosyal bilim öğrencilerinin hem öğrenimlerinin bir gereksinimini yerine getirmeleri, hem de bu gereksinimden alışkanlık kazanmaları nedeniyle fen bilimleri 
öğrencilerine oranla daha yüksek bir okuma alışkanlığı becerisine sahip olmaları, dolayısıyla kütüphane kullanımına daha fazla istekli olacakları beklenir.

Tablo 14. Bilim dallarına göre öğrencilerin kütüphane memnuniyeti düzeyi

\begin{tabular}{|c|c|c|c|c|c|c|}
\hline \multirow{3}{*}{$\begin{array}{l}\text { ‘Kütüphaneye } \\
\text { gitmekten zevk } \\
\text { duyarım' ifadesine } \\
\text { verilen yanıtlar }\end{array}$} & \multicolumn{4}{|c|}{ Bilim Alanları } & & \\
\hline & \multicolumn{2}{|c|}{ Fen Bilimleri } & \multicolumn{2}{|c|}{ Sosyal Bilimler } & \multicolumn{2}{|c|}{ Toplam } \\
\hline & $\mathbf{N}$ & $\%$ & $\mathbf{N}$ & $\%$ & $\mathbf{N}$ & $\%$ \\
\hline \multirow{2}{*}{$\begin{array}{l}\text { Cevap yok } \\
\text { Tamamen }\end{array}$} & 8 & 5,3 & 8 & 5,2 & 16 & 5,3 \\
\hline & 23 & 15,2 & 15 & 9,8 & 38 & 12,5 \\
\hline $\begin{array}{l}\text { katılıyorum } \\
\text { Katılıyorum }\end{array}$ & 44 & 29,1 & 38 & 24,8 & 82 & 27,0 \\
\hline \multirow{2}{*}{$\begin{array}{l}\text { Fikrim yok } \\
\text { Katılmıyorum }\end{array}$} & 32 & 21,2 & 36 & 23,5 & 68 & 22,4 \\
\hline & 31 & 20,5 & 35 & 22,9 & 66 & 21,7 \\
\hline $\begin{array}{l}\text { Kesinlikle } \\
\text { katılmıyorum }\end{array}$ & 13 & 8,6 & 21 & 13,7 & 34 & 11,2 \\
\hline Toplam & 151 & 100 & 153 & 100 & 304 & 100 \\
\hline
\end{tabular}

Ancak Tablo 14'te sosyal bilimler lehine olması beklenen kütüphane isteminin fen bilimleri öğrencilerinde daha yüksek olduğu görülmektedir. Örneğin tabloda fen bilimi öğrencilerinin \% 44,3'ü, sosyal bilim öğrencilerinin \% 34,6 kütüphaneye gitmekten zevk aldığını belirtmektedir. Öğrencilerin yaklaşık \% 33'ünün kütüphaneye gitmekten zevk almadıklarını ifade etmesi ise kütüphanelerin kullanıcı politikalarının yeniden değerlendirilmesi gerektiğine işaret etmektedir. Bu sonuçlar özellikle üniversite kütüphanelerin bilim dallarına göre öğrenciler arasındaki kullanım farklarının dengelenmesi ve kullanımın artırılması amacıyla yeniden yapılanmalarını zorunlu kılmaktadır.

\section{Öğrenci Etkinlikleri ve Harcamaları}

Son yıllarda özellikle gençler arasında görülen bazı günlük etkinlikler okuma eyleminin yerini almış ve okumaya ayrılması gereken zamanın neredeyse yok olmasına neden olmuştur. Müzik dinleme, televizyon izleme ve bilgisayar kullanma bu etkinlikler arasında sayılabilir. Bunların okuma eylemi üzerinde görülen olumsuz yansımaları, üniversite öğrencileri üzerinde daha belirgin biçimde ortaya çıkmaktadır. Bu nedenle ankette öğrencilerin müzik dinleme, televizyon izleme ve bilgisayar kullanımı konusunda günlük ortalama harcadıkları zamanın belirlenmesine yönelik sorulara da yer verilmiştir. 
Tablo 15. Cinsiyete göre öğrencilerin bir günde ortalama müzik dinlemeye ayırdıkları süre

\begin{tabular}{|c|c|c|c|c|c|c|}
\hline \multirow[b]{2}{*}{ Dinleme süresi } & \multicolumn{4}{|c|}{ Cinsiyet Türü } & \multirow[b]{2}{*}{$\begin{array}{l}\text { Toplam } \\
\mathbf{N}\end{array}$} & \multirow[b]{2}{*}{$\%$} \\
\hline & $\mathrm{N}^{\mathrm{K} / \mathrm{z}}$ & $\%$ & $\begin{array}{l}\text { Erkek } \\
\mathrm{N}\end{array}$ & $\%$ & & \\
\hline Cevap yok & 1 & 0,7 & 2 & 1,3 & 3 & 1,0 \\
\hline $0-0,5$ saat & 20 & 13,1 & 32 & 21,2 & 52 & 17,1 \\
\hline $0,5-0,9$ saat & 34 & 22,2 & 53 & 35,1 & 87 & 28,6 \\
\hline $1-1,9$ saat & 42 & 27,5 & 35 & 23,2 & 77 & 25,3 \\
\hline 2 saatten çok & 56 & 36,6 & 29 & 19,2 & 85 & 28,0 \\
\hline Toplam & 153 & 100 & 151 & 100 & 304 & 100 \\
\hline
\end{tabular}

Tablo 15’teki cinsiyetine göre öğrencilerin günlük ortalama müzik dinleme süresine ilişkin veriler incelendiğinde, bir günde müzik dinlemeye erkeklerin \% 21,2'si, kızların \% 13,1'i tablonun en alt dilimi olan 0-0,5 saatlik bir süre harcamaktadır. Tablodaki verilere genel olarak bakıldığında, harcama süresi yükseldikçe kızların gösterdikleri ilgide artışın olduğu görülmektedir. Örneğin kızların \% 27,5'ine karşın erkeklerin \% 23,2'si müzik dinleme faaliyetine günlük 1-2 saat harcamaktadır. Benzer şekilde günlük 2 saatten fazla müzik dinleyen \% 36,6'lık kız öğrenciye karşın erkek öğrencilerin oranı sadece \% 19,2 olarak belirlenmiştir. Bu tabloda en dikkat çekici olan veri ise öğrencilerin yarısından fazlasının ( $\%$ 53) gününün 1,5 saatini müzik dinlemeye ayırıyor olmasıdır.

Tablo 16. Cinsiyete göre öğrencilerin bir günde ortalama televizyon izlemeye ayırdıkları süre

\begin{tabular}{|c|c|c|c|c|c|c|}
\hline \multicolumn{7}{|c|}{ Cinsiyet Türü } \\
\hline \multirow[t]{2}{*}{ İzleme süresi } & \multicolumn{2}{|c|}{$\mathrm{K} / \mathrm{z}$} & \multicolumn{2}{|c|}{ Erkek } & \multicolumn{2}{|c|}{ Toplam } \\
\hline & $\mathbf{N}$ & $\%$ & $\mathbf{N}$ & $\%$ & $\mathbf{N}$ & $\%$ \\
\hline Cevap yok & 2 & 1,3 & 3 & 2,0 & 5 & 1,6 \\
\hline $0-0,5$ saat & 40 & 26,1 & 45 & 29,8 & 85 & 28,0 \\
\hline $0,5-0,9$ saat & 31 & 20,3 & 32 & 21,2 & 63 & 20,7 \\
\hline $1-1,9$ saat & 55 & 35,9 & 47 & 31,1 & 102 & 33,6 \\
\hline 2 saatten çok & 25 & 16,3 & 24 & 15,9 & 49 & 16,1 \\
\hline Toplam & 153 & 100 & 151 & 100 & 304 & 100 \\
\hline
\end{tabular}

Günde ortalama televizyon izleme sürelerinin verildiği Tablo 16 verilerine göre, izleme süresi olarak en fazla yarım saat diyenlerin oranı $\% 28$, en fazla bir saat diyenler $\% 20,7$, en fazla iki 
saat diyenler \% 33,6 ve iki saatten çok izlerim diyenler ise \% 16,1 'dir. Müzik dinleme eğiliminde olduğu gibi televizyon izlemede de kızların oranının erkeklerden yüksek olduğu anlaşılmaktadır. Ayrıca katılımcıların yaklaşık \% 50'sinin günde en az bir saat televizyon izlediği görülmektedir. Ancak katılımcıların önemli bir bölümünün yurtlarda kaldığı ve kendilerine özel bir televizyonlarının olmadığı göz önüne alındığında, bu oranların kendilerine özel ortamlarda daha da yukarı çıkacağı düşünülebilir.

Tablo 17 'de ise öğrencilerin oyun, eğlenme ve sohbet etme gibi amaçlarla bir günde ortalama bilgisayar başında geçirdiği süreler gösterilmektedir. Çıkan değerlerin birbirine yakın olması nedeniyle bilgisayar başında geçirilen süre ile cinsiyet arasında anlamlı bir ilişkinin varlığından söz edilemez. Öğrencilerin \% 24'ü günlük ortalama en az yarım, en fazla bir saatlik süresini bilgisayar başında geçirdiklerini ifade etmektedirler. Öğrencilerin yarısına yakını (\% 49) da vakitlerinin en az bir saatini bilgisayar başında harcadıklarını söylemektedir. Bireysel tercihlere göre zamanın iki saatten daha fazlasını bilgisayar üzerinde harcayan öğrenci oranı ise \% 25 gibi önemli bir düzeye çıkmaktadır.

Tablo 17. Cinsiyete göre öğrencilerin bir günde ortalama bilgisayar başında geçirdikleri süre

\begin{tabular}{|c|c|c|c|c|c|c|}
\hline \multicolumn{7}{|c|}{ Cinsiyet Türü } \\
\hline \multirow{2}{*}{$\begin{array}{l}\text { Vakit geçirme } \\
\text { süresi }\end{array}$} & \multicolumn{2}{|c|}{ KIz } & \multicolumn{2}{|c|}{ Erkek } & \multicolumn{2}{|c|}{ Toplam } \\
\hline & $\mathbf{N}$ & $\%$ & $\mathbf{N}$ & $\%$ & $\mathbf{N}$ & $\%$ \\
\hline Cevap yok & 4 & 2,6 & 3 & 2,0 & 7 & 2,3 \\
\hline $0-0,5$ saat & 25 & 16,3 & 28 & 18,5 & 53 & 17,4 \\
\hline $0,5-0,9$ saat & 31 & 20,3 & 42 & 27,8 & 73 & 24,0 \\
\hline $1-1,9$ saat & 39 & 25,5 & 33 & 21,9 & 72 & 23,7 \\
\hline 2 saatten çok & 38 & 24,8 & 38 & 25,2 & 76 & 25,0 \\
\hline Hiç & 16 & 10,5 & 7 & 4,6 & 23 & 7,6 \\
\hline Toplam & 153 & 100 & 151 & 100 & 304 & 100 \\
\hline
\end{tabular}

Son üç tablonun genel ortalamasına bakıldığında müzik dinleme, televizyon izleme ve bilgisayar kullanma için günlük en az bir saatten fazla vakit ayıran öğrencilerin ortalaması \% 51'e denk gelmektedir. Öğrencilerin yarısının söz edilen her üç faaliyet için ortalama ikişer saatten olmak üzere günlük toplam 6 saatini müziğe, televizyon yayınına ve bilgisayar başında eğlenmeye harcaması oldukça düşündürücü bir durumdur. Öğrencilerin yalnızca yaklaşık 
\% 37'sinin günde en fazla bir saatini okumaya ayırması (Bkz. Tablo 3), dinlence faaliyetlerine okumadan daha fazla zaman ayırdıklarını ortaya koymaktadır. Müziğin, televizyon yayınlarının ve bilgisayar kullanımının zararığı olduğu elbette düşünülemez. Ancak söz konusu etkinliklere gösterilen aşırı ilgi, yapılması gerekli diğer faaliyetlerin göz ardı edilmesine neden olmaktadır.

\section{Sonuç ve Öneriler}

Elde edilen bulgulardan hareketle üniversite öğrencilerinin okuma kültürü konusunda şu sonuçlara varılmıştır:

- $\quad$ Öğrencilerin önemli bir bölümü düşük bir okuma kültürüne sahiptir. Oranı düşük olsa da bir yıl içinde hiç kitap okumayan öğrencilerin varlığı, üniversite öğrencisi için beklenmedik bir durumdur.

- $\quad \mathrm{K}$ ız öğrencilerinin erkeklere oranla okuma etkinliğine daha fazla süre ayırdıkları görülmektedir.

- Öğrencilerin önemli bir kısmı okumamalarını ekonomik sorunlara dayalı nedenlerle açıklamaktadır. Ancak alt düzey sosyo-ekonomik sınıf içinde olduklarını belirten öğrencilerin üst düzey sosyo-ekonomik sınıfta yer alan öğrencilerle eşit okuma oranına sahip olması ileri sürdükleri bu nedeni doğrulamamaktadır.

- OÖğrencilerin büyük bir bölümü okumalarını engelleyen en önemli neden olarak çalışma yoğunluğu ve ekonomik sorunları ifade etmektedir. Bununla birlikte öğrencilerin, bir gün içinde yaptığı dinlence faaliyetlerine oranla okumaya çok daha az zaman harcadıkları görülmektedir.

- Üniversite öğrenimlerinin ilk yıllarında daha az okuyan öğrencilerin, son yıllara doğru okuma eğilimleri artmaktadır. Ancak tespit edilen bu oran, bir üniversite öğrencisi için olması gereken düzeyin oldukça altındadır.

- $\quad$ Ebeveyni düşük eğitim düzeyine sahip olan öğrencilerin okuma alışkanlıklarının da zayıf olduğu, buna karşın eğitimli 
anne-babanın çocuklarının daha yüksek bir okuma kültürüne sahip oldukları görülmektedir.

- $\quad$ Öğrencilerin önemli bir bölümü kütüphanelerden yararlanmamakta ve kütüphaneye gitmekten zevk duymamaktadır.

- Kütüphane kullanımı konusunda kız öğrenciler erkek öğrencilere kıyasla daha istekli durumdadır.

- Beklenenin aksine sosyal bilim öğrencileri fen bilimi öğrencilerine oranla kütüphane kullanımından daha az zevk almaktadırlar.

- $\quad \mathrm{K} ı$ öğrencilerin televizyon izleme ve müzik dinlemeye olan eğilimi erkek öğrencilerden daha yüksektir.

- Öğrencilerin yarıya yakını vakitlerinin önemli bir kısmını televizyon izlemeye, müzik dinlemeye ve bilgisayar kullanmaya ayırmaktadır. Buna karşın kitap okumaya ayrılan süre söz edilen faaliyetlerin toplam süresinin çok altında kalmaktadır.

Üniversite öğrencilerinin okuma kültürüne bakıldığında çıkan sonucun Türk halkının genel yapısına oranla daha iyi bir görünüme sahip olduğu söylenebilir. Ancak üniversiteler gibi okuma, araştırma ve öğrenme temeli üzerinde sürdürülen bir sistemde, bu verilerin olumlu bir tablo olduğunu söylemek güçtür. Okuma alışkanlığı aile ve ilköğretim kurumlarında kök salmaya başlar. Bu dönemlerde kazanılamayan alışkanlıkların ilerleyen dönemlerde oluşamayacağını söylemek de doğru olmaz, diğer bir ifade ile okuma alışkanlığı geç dönemlerde de başlayabilir ve hayatın her döneminde gelişme gösterebilir. Yüksek öğretim sistemi bir bireyin meslek yaşamına atılmadan önce aldığı son formel öğrenim programıdır. Bu nedenle üniversiteler bireyin mesleki alanda uzmanlaşmasını sağlamanın yanı sıra kişisel gelişimini destekleyecek programlara da sahip olmalıdır.

$\mathrm{Bu}$ değerlendirmeler çerçevesince üniversite öğrencilerine okuma alışkanlığı kazandırılmasına ve/veya geliştirilmesine ilişkin öneriler şu şekilde sıralanabilir: 
- $\quad$ Bir üniversite kütüphanesinde bulunması gereken derme göz önünde bulundurularak mevcut kütüphane dermesinin analizi yapılmalıdır. Daha sonra öğrencilerin kütüphaneyi ilgi çekici bir yer olarak görmemelerinin nedenlerini belirleyebilmek için geniş ölçekli bir araştırma yapılmalı ve sorunlar tespit edilmelidir. Öğrencilerin okuma gereksinimini belirlemeye yönelik akademik birimlerle işbirliği yapılmalı ve akademik birimlerin görüşleri dikkate alınmalıdır. Elde edilen bulgular kütüphane politikasının öğrencilerin okuma ve kütüphane kullanımı istemini teşvik edici biçimde yeniden düzenlenmesi için kullanılmalıdır.

- Kütüphane dermesi kullanıcıların her tür beklentisini karşılayacak nitelik ve niceliğe uygun biçimde oluşturulmalıdır. Bu konuda özellikle klasikler ve popüler yayınlarla birlikte her türde dergi ve gazete aboneliğinin gençler arasında daha çok ilgi göreceği dikkate alınmalıdır.

- Kütüphane tarafından okuma programları düzenlenmelidir. Okuma programları öğrencilerin ilgi alanlarına, öğrenim gördükleri programların seviyesine ve türüne göre çeşitlilik göstermelidir. Bu programlar aracılığıyla öğrenciler okuma konusunda motive edilmeli ve aynı zamanda kişisel gereksinimlerini karşılayacak bilgi kaynaklarına nasıl erişecekleri konusunda bilinçlendirilmelidirler. Bu amaçla kütüphanenin okuyucu hizmetleri biriminde öğrencilerin ilgi alanlarına uygun kaynakları bulmalarına yardımcı olma, bu doğrultuda öneriler sunma ve öğrenciyi yönlendirme hizmetlerine daha fazla önem verilmelidir.

- Kütüphanenin, akademik birimlerinin ve üniversite yönetiminin desteği ile öğrencilerin okuma toplulukları oluşturması sağlanmalıdır. Bu konuda üniversite yönetiminin en önemli görevi okuma toplulukları tarafından istenen ve kütüphane tarafından önerilen kaynakları sağlamak ve geliştirilen programları bütünüyle desteklemektir. 
- Özellikle yurtlarda kalan öğrenciler için kütüphanelerin alternatif bir çalışma ve dinlenme alanı olduğu bir gerçektir. Bu nedenle kütüphaneler her yönüyle rahat bir okuma ortamına kavuşturulmalıdır.

\section{Kaynakça}

Adrese dayalı nüfus kayıt sistemi (ADNKS) 2007 nüfus sayım sonuçları. (2007). 20 Şubat 2008 tarihinde http://tuikapp.tuik.gov.tr/adnks dagitimapp/adnks.zul adresinden erişildi.

Aksaçlıoğlu, A.G. ve Yılmaz, B. (2007). Öğrencilerin televizyon izlemeleri ve bilgisayar kullanmalarının okuma alışkanlıkları üzerine etkisi. Türk Kütüphaneciliği, 21(1), 3-28.

Aktaş, Ş. ve Gündüz, O. (2004). Yazılı ve sözlü anlatım: Kompozisyon sanatı. Ankara: Akçağ.

ALA. (1978). Bookreading and library usage. A study of habits and perceptions. New Jersey: Gallup.

Bamberger, R. (1990). Okuma alışkanlığını geliştirme (B. Çapar, Çev.). Ankara: Kültür Bakanlığı Kütüphaneler Genel Müdürlüğü.

Book production: Number of titles by UDC classes. (2000). 20 Ekim 2007 tarihinde http://stats.uis.unesco.org/unesco/TableViewer/ tableView.aspx?Reportld=202 adresinden erişildi.

Census 2001. (2001). 20 Şubat 2008 tarihinde http://www.statistics.gov.uk/census2001/pop2001/united_kingdo m.asp adresinden erişildi.

Çıngı, H. (1990). Örnekleme kuramı. Ankara: Hacettepe Üniversitesi.

Darko-Ampem, K. (2004). Reading habits of standard 5-7 pupils in Gaborone, Botswana: A pilot survey. 12 Ekim 2004 tarihinde http://www.sacbf.org.za/2004\%20papers/Kwasi\%20DarkoAmpem.rtf adresinden erişildi.

Elliot, J. (2007). Academic libraries and extracurricular reading promotion. Reference \& User Services Quarterly, 46(3), 34-43. 
Ersoy, A. (2007). Hacettepe Üniversitesi Türk Dili ve Edebiyatı Bölümü son sınıf öğrencilerinin okuma alışkanlıkları. S. Kurbanoğlu, Y. Tonta ve U. Al (Yay.Haz.). Değişen Dünyada Bilgi Yönetimi Sempozyumu 24-26 Ekim 2007, Ankara Bildiriler içinde (ss. 179-184). Ankara: Hacettepe Üniversitesi Bilgi ve Belge Yönetimi Bölümü.

Gençler ne düşünüyor araştırması. (2008). 26 Şubat 2008 tarihinde http://www.artidusunce.org/index.php?option=com_content\&task =view\&id=14\&ltemid=32 adresinden erişildi.

Gönen, M., Öncü, E.Ç. ve Işıtan, S. (2004). İlköğretim5., 6. ve 7. sınıf öğrencilerinin okuma alışkanlıklarının incelenmesi. Milli Eğitim Eğitim-Kültür-Sanat, Güz (164). 20 Aralık 2007 tarihinde http://yayim.meb.gov.tr/dergiler/164/gonen.htm adresinden erişildi.

Haftalık ortalama gazete satışları: Tirajedi raporu 01 - 07 Kasım 1999. (1999). 20 Şubat 2008 tarihinde http://www.dorduncu kuvvetmedya.com/arsiv/tiraj.htm adresinden erişildi.

Iki saatten fazla televizyon dikkat dağıtıyor. (2007). 4 Nisan 2007 tarihinde http://arama.hurriyet.com.tr/arsivnews.aspx?id= 7216455 adresinden erişildi.

Istatistikler. (2008). 10 Şubat 2008 tarihinde http://kygm. kulturturizm.gov.tr/BelgeGoster.aspx?F6E10F8892433CFF0D26 2A49C727F232C312D1DD2E9EA986 adresinden erişildi.

Koç, S. ve Müftüoğlu, G. (2008). Dinleme ve okuma öğretimi. 21 Şubat 2008 tarihinde www.aof.anadolu.edu.tr/kitap/lOLTP/2277/ unite04.pdf adresinden erişildi.

Koçal, E. (2004). Televizyon çocukları uyuşturuyor. 21 Şubat 2008 tarihinde http://arsiv.sabah.com.tr/2004/09/01/cp/yas11420040821-101.html adresinden erişildi.

Lehr, F. (1981). Television viewing and reading. Reading Teacher, 35(2), 230-233. 
Ortaş, İ. (2007). Kitap okuma alışkanlığı nasıl kazandırıır? Kitap okuru bir toplum muyuz?-2. 12 Ekim 2007 tarihinde http://www.hakimi yetimilliye.org/index.php?news $=864$ adresinden erişildi.

Önder, Z. (2002). The Economics of Tobacco in Turkey: New Evidence and Demand Estimates. Washington: DC, The World Bank.

Özdamar, K. (1997). Paket programlar ile istatistiksel veri analizi. Eskişehir: Anadolu Üniversitesi.

Özdemirci, F. (1990). "Niçin az okuyoruz" kamuoyu araştırması sonuçlandı. Türk Kütüphaneciliği, 4(3), 154-155.

Phillip, A. (2005). The Reading habit - A missing link between literacy and libraries. 2 Mayıs 2007 tarihinde http://www.pngbuai.com/sitenews/default.htm adresinden erişildi.

Public libraries. (2001). 12 Ekim 2007 tarihinde http://stats.uis.unesco.org/unesco/TableViewer/tableView.aspx? Reportld=207 adresinden erişildi.

Rating-Tiraj. (2008). 12 Şubat 2008 tarihinde http://www.netgazete.com/ adresinden erişildi.

Reading skills for university. (1997). 20 Ekim 2007 tarihinde http://www.nwcc.bc.ca//rc/skills.cfm adresinden erişildi.

Sağlamtunç, T. (1990). Türkiye'de üniversite kütüphanecilik bölümlerinin 4. Sınıf öğrencilerinin özgür (boş) zaman ders dışı okuma alışkanlıkları üzerine bir araştırma. Türk Kütüphaneciliği, 4(1), 3-21.

Sangkaeo, S. (1999). "Reading habit promotion in ASEAN libraries", 65th IFLA Council and General Conference Bangkok, Thailand, August 20 - August 28, 1999. 12 Ocak 2005 tarihinde http://www.ifla.org//V/ifla65/papers/091-114e.htm adresinden erişildi.

Televizyon ve otizm. (2008). 25 Şubat 2008 tarihinde http://www.4yw. org/televizyon-ve-otizm.html adresinden erişildi.

Türkiye İstatistik Enstitüsü Kurumu. (2007a). Kütüphane türlerine göre kütüphanelerden yararlananlar, kayıtlı üye ve personel 
sayısı, 1993-2003. 10 Mart 2007 tarihinde http://www.tuik.gov.tr/ PrelstatistikTablo.do? istab_id=107 adresinden erişildi.

Türkiye İstatistik Enstitüsü Kurumu. (2007b). Türlerine göre kütüphane, kitap ve kitap dışı materyal sayısı, 1993-2003. 10 Şubat 2007 tarihinde http://www.tuik.gov.tr/relstatistikTablo.do? istab_id=109 adresinden erişildi.

World Association of Newspaper-World Press Trends 2005. (2005). 20 Şubat 2008 tarihinde http://www.wanpress.org/worldpresstrends/articles.php?id=18 adresinden erişildi.

World Association of Newspaper-World Press Trends 2006. (2006). 20 Şubat 2008 tarihinde http://www.wan-press.org/ worldpresstrends/articles.php?id=18 adresinden erişildi.

Yılmaz, B. (1993). Okuma alışkanlığında halk kütüphanelerinin rolü. Ankara: Kültür Bakanlığı Kütüphaneler Genel Müdürlüğü.

Yılmaz, B. (1995). Okuma sosyolojisi: Ankara'da oturanların okuma alışkanlıkları üzerine bir araştırma. Türk Kütüphaneciliği, 9(3), 325-336.

Yılmaz, B. (2004). Öğrencilerin okuma ve kütüphane kullanma alışkan-lıklarında ebeveynlerin duyarlılığı. Bilgi Dünyası, 5(2), 115-136.

Yulia, A. (2006). How to increase children's reading habit in a developing country. 12 Nisan 2006 tarihinde http://ezinearticles.com/?How-to-Increase-Childrens-ReadingHabit-in-A-Developing-Country\&id=75980 adresinden erişildi. 